\title{
ETIKA KOMUNIKASI DALAM VEDA (TINJAUAN FENOMENOLOGI PADA ERA GLOBALISASI)
}

\author{
Oleh : \\ Untung Suhardi \\ Wayan Tantre Awiyane
}

\begin{abstract}
This research using triggered with the phenomenon that it is this day of the importance of the application of ethics in the life of, especially ethical in the vedas that exist in the life of religious social .This research using analysis deksriptif qualitative done with the approach phenomenology in of life at literature hindu. Research discussed about the history of communication in the vedas, ethics communication in the vedas and efforts the preservation of the implementation of the communication in the life of religious social. The result of this research showed that form of communication which limited only speak to your neighbor, but hindu give the findings for donations to civilization mankind that communication the most essential relationships are vertical with the almighty.Communication used in basic hindu thought this is what made the concept of the balance between spiritual life and a globe which is later, becomes the basis for behavior communicate in life in the present.In relation to the process communication veda is very long apply pattern interaction with your neighbor and its environment good horizontally with fellow human beings began of the family, the community and even to the national interest and state.Their effort to preserve ethics communication in the vedas formed by openness individual, the integration of all components hindu, capital intellectual as turning point in progress human resources, and sanction to local knowledge.
\end{abstract}

Keywords: Ethical communication, the vedas, globalization, and phenomena.

\section{A. Latar Belakang}

Perjalanan bangsa ini membawa pengaruh yang memberikan kesan bahwa religius yang telah diberikan oleh negara lain secara perlahan luntur oleh segelintir orang yang berniat untuk menghilangkan citra baik bangsa. Seiring dengan perkembangan waktu bahwa masyarakat Indonesia terkesan telah mengabaikan nilai-nilai agama karena secara skala prioritas telah mengutamakan harta dan pangkat dan nilai kemanusiaan seolah-olah hilang karena permasalahan persoalan yang hanya memberikan kepuasan yang bersifat sementara ${ }^{1}$.

Kesan yang banyak sekali muncul pada keadaan bangsa Indonesia ini adalah kehilangan kepercayaan diri sebagai bangsa yang multikultural. Hal ini yang telah

\footnotetext{
${ }^{1}$ Anak Agung Raka Mas. Upaya Mengeliminasi Kehidupan Dehumanisasi Manusia Menuju Kehidupan bahagia Paripurna Di Era Globalisasi (Pendekatan Filsafat Manusia Dalam Ajaran Hindu) (Denpasar: IHDN, 2013), hal : 6.
} 
dirusak oleh paham untuk mendirikan bangsa ini dalam satu agama dan hanya beberapa etnis saja sedangkan yang lain diabaikan. Upaya yang terkesan muncul ini sangat terlihat jelas pada pengkotak-kotakan bangsa Indonesia yang hanya dibedakan atas agama dan $\operatorname{ras}^{2}$. Padahal ketika kita berbicara kemajemukan bangsa Indonesia kita harus berkaca bahwa bangsa yang besar ini terdiri dari ribuan pulau, bahasa, etnis, budaya dan hal lainnya. Keanekaragaman ini sebagai kekayaan bangsa yang membedakan dengan bangsa lain, hal ini sebagai modal yang tidak ternilai oleh material apapun didunia ini. Perjalanan ini memberikan pengaruh secara mental bahwa kebhinekaan Indonesia ini menjadi tanggungjawab yang sangat besar kepada seluruh insan Indonesia untuk melestarikannya demi kelangsungan bangsa dan negara ini. Dalam kehidupan sehari-hari manusia tidak akan pernah lepas dari komunikasi. Dari mulai kita bangun tidur sampai kemudian tertidur kembali, komunikasi selalu menjadi kegiatan utama kita baik itu komunikasi verbal atau non verbal, baik komunikasi antarpribadi atau komunikasi organisasi.

Hal seperti ini memang telah menjadi kodrat kita sebagai seorang manusia yang memang tidak dapat hidup sendiri. Kita selalu membutuhkan orang lain disekitar kita, walaupun hanya untuk sekedar melakukan obrolan basa-basi karena manusia adalah makhluk sosial dan dari interaksi itulah manusia lambat laun menciptakan nilai-nilai bersama yang kemudian disebut sebagai kebudayaan ${ }^{3}$. Dalam nilai-nilai yang terbentuk tersebut terdapat beberapa kaidah yang bertujuan mengatur tata cara kita berkomunikasi antar sesama tanpa menyakiti hati dan menjunjung tinggi etika sebagai sebuah tanda penghargaan pada lawan bicara kita. Namun terkadang pemakaian sesuatu yang kita anggap sebuah etika dapat berakibat pada sesuatu yang tidak menyenangkan dan menimbulkan kesalahpahaman antar sesama.

Pemakaian etika dalam konteks komunikasi antarpribadi memiliki paradoks tersendiri. Di lain pihak, hal ini dapat menjadi hal yang positif namun terkadang

${ }^{2}$ Putu Setia. Kebangkitan Hindu Menyongsong Abad 21 (Jakarta : Pustaka Manikgeni, 1993), hal : 3. Perseteruhan yang diperdebatkan dalam tulisan Putu setia menjelaskan bahwa kepandaian yang dimiliki oleh cendikiawan harus dibarengi dengan etika, sehingga agama dan pengetahuan harus sejalan. Hal sebaliknya yang terjadi ketika mengabaikan nilai keseimbangan ini adalah melahirkan kelompok yang ekslusif yang mengusung pandangan bahwa kelompoknya paling baik menganggap kelompok lain buruk. Hal ini diperparah lagi dengan keadaan bangsa yang ditekan oleh beberapa oknum untuk menggunakan sekulerisme sebagai pedoman baik dalam kehidupan bermasyarakat maupun bernegara.

${ }^{3}$ Koentjaraningrat. Sejarah Teori Antropologi (Jakarta : UI Press, 1987), hal : 111 
sesuatu yang negatif dan cenderung merusak dan memperburuk keadaan juga dapat terjadi. Berbagai hal dinilai bertanggung jawab atas hal ini, dari mulai cara kita berkomunikasi antar sesama sampai pada saat kita menggunakan etika dalam berinteraksi. Pola interaksi yang dilakukan dalam kehidupan ini menjadikan bahan kajian yang kemudian menjadikan orang mampu untuk menjalin hubungan yang harmonis yang dalam ajaran Hindu dikenal dengan konsep tri hita karana. Wujud inilah yang kemudian berkembang menjadi pola keseimbangan antara Tuhan, manusia dan alam secara skala dan niskala, kemudian tentang hubungan yang harmonis dalam pikiran, perkataan dan perbuatan yang tertuang dalam tri kaya parisudha. Untuk itulah, dalam tulisan ini diketengahkan tentang permasalahan yang berkaitan dengan aspek komunikasi yang ada dalam Veda. Hal ini perlu untuk diketengahkan karena penulis dalam hal ini merasa tergugah dengan adanya kenyataan yang ada dalam kehidupan bahwa keberadaan laju modernitas sangat pesat sehingga perlu diimbangi dengan ilmu agama sebagai pedoman dalam kehidupan yang penuh dengan dinamika.

Keterkaitan dengan pola pemikiran ini adalah dengan etika yang tidak hanya melakukan interaksi dengan Tuhan dan sesama manusia, melainkan juga ada keterkaitan hubungannya dengan alam. Pemikiran Heideger memberikan sumbangan positif pada arah keseimbangan tentang interaksi manusia dan alam ${ }^{4}$. Heideger memberikan penjelasan adalah keseimbangan akan terjadi ketika manusia mampu untuk menyatukan pikiran, kebudayaan dan teknologi. Penjelasan interaksi ini dalam tri kaya parisudha sebagai bentuk nyata dari manacika, wacika dan kayika yang kemudian, diaktualisasikan dalam kehidupan nyata. Untuk kemudian, pola interaksi ini menjadikan bagian dari etika komunikasi dalam Veda yang ada dalam kehidupan modern.

Pemaknaan penulis dalam hal ini adalah untuk mengusung pemahaman baru yang sangat kental dengan pola pemikiran yang bertujuan untuk memberikan secercah pemahaman baru tentang komunikasi dalam Veda. Hal ini diperlukan karena penulis menyadari bahwa komunikasi tidak hanya sebatas interaksi dengan sesama manusia, melainkan bahwa komunikasi adalah aspek etika dan estetika yang ingin disampaikan komunikator kepada komunikan. Oleh sebab itulah,

${ }^{4}$ LG. Saraswati Putri. Dimensi Ontologis Relasi Manusia dan Alam (suatu pendekatan fenomenologis lingkungan terhadap problem disekuilibrium). (Depok : UI Press, 2013), hal : 18. 
komunikasi dalam Veda yang akan penulis sajikan ini akan berbicara dalam aspek wicara baik itu dalam kaitannya dengan kehidupan keagamaan maupun sosial. Penjelasan tentang etika komunikasi inilah yang nanti sebagai bekal dalam kehidupan yang tidak hanya untuk kehidupan sosial melainkan juga untuk kegiatan dalam lingkup keagamaan yang sarat akan suatu hal yang sakral. Hal ini seperti, keberadaan kitab suci, waktu persembahan, tempat ibadah dan hal lain yang terkait dengan dimensi agama. Terkait dengan uraian ini menunjukan bahwa ilmu komunikasi sebagai bagian dari ilmu pengetahuan yang selalu berkembang. Oleh karena itu, interaksi komunikasi sangat diperlukan baik dalam lingkup agama maupun dalam kehidupan sehari-hari.

Terkait dengan uraian di atas menunjukan bahwa ada ketertarikan penulis tentang etika yang perlu untuk dihadirkan dalam kehidupan sehari-hari berhubungan dengan komunikasi yang ada dalam kehidupan. Ajaran agama Hindu mempunyai konsep yang sangat dalam tentang pola interaksi baik itu secara vertikal maupun horizontal yang dalam hal ini masih banyak misteri yang terpendam. Untuk itulah, dalam penelitian ini penulis akan mengungkap tentang ajaran komunikasi yang tertuang dalam ajaran Veda baik itu ajaran yang terkandung dalam Sruti sebagai otoritas Veda yang pertama maupun smrti sebagai otoritas Veda yang kedua.

\section{B. Rumusan Masalah}

Melanjutkan gagasan ini maka penulis dalam hal ini akan menghadirkan pembahasan tentang tema etika komunikasi dalam Veda. Pembahasan ini terbagi menjadi beberapa ulasan, yaitu bagaimanakah sejarah komunikasi dalam Veda, bagaimanakah perspektif etika komunikasi yang ada dalam Veda ?, bagaimanakah upaya pelestarian etika komunikasi dalam Veda untuk diterapkan dalam kehidupan sehari-hari terkait dengan kegiatan sosial keagamaan umat Hindu?. Sejalan dengan pemikiran inilah penulis secara beriringan akan membahas terkait dengan permasalahan yang telah ada kemudian dianalisis menggunakan pisau analisis yang ada.

\section{Tujuan dan Manfaat}

Berkaitan dengan permasalahan dan pertanyaan kunci tersebut bahwa isi tulisan ini dalam hal kehadiran pembahasan mempunyai tujuan yang mengacu pada pokok pembahasan tentang upaya untuk memperdalam tentang sejarah 
komunikasi dalam Veda, memperdalam pemahaman tentang etika komunikasi dalam Veda dan upaya pelestarian etika komunikasi Veda kaitannya dengan penerapannya dalam kehidupan sehari-hari. Kemudian manfaat dalam hal ini secara umum adalah sebagai pedoman secara nyata bahwa etika komunikasi adalah sangat penting dalam berbagai segi kehidupan, sehingga seluruh manusia dapat menerapkannya sesuai dengan kadar kemampuan individu yang bersangkutan. Jadi, tulisan ini diharapkan menjadi sumbangan yang secara praktis dalam kehidupan bermasyarakat baik dalam kehidupan sosial maupun lingkup keagamaan.

\section{Metode Penelitian}

Penelitian yang dilakukan termasuk dalam penelitian kualitatif yang bekerja dalam setting yang alami untuk berupaya memahami, memberi tafsiran terhadap fenomena yang dilihat ${ }^{5}$. Oleh karena itu dari sudut sifat penelitian merupakan penelitian eksploratoris(explorative research) yang dalam hal ini sifatnya adalah penjajakan yang dalam penemuan data masih sangat dasar sekali. Bertujuan untuk mengamati pelaksanaan komunikasi yang ada.

Data sekunder ini merupakan sumber yang tidak langsung namun, bisa memberikan data kepada pengumpulan data, misalnya yang berasal dari kepustakaan, artikel, majalah, skripsi, tesis, disertasi, jurnal dan dokumen lain yang merupakan hasil penelitian atau buku-buku yang relevan dengan penelitian. Selain itu, dalam menggunakan data skunder ini juga diperlukan internet ${ }^{6}$ sebagai referensi penunjang terkait artikel yang berkaitan dengan etika komunikasi yang ada dalam Veda. Dengan demikian, setelah semua data terkumpul maka dilakukan edit data dengan melengkapi data serta menyusunnya dengan cara mengklasifikasi menurut bab atau subbab dan bagian uraiannya yang dalam hal ini perlu adanya koding dengan memberikan nomor atau huruf untuk memudahkan analisa data. Langkah kodifikasi data ini dilakukan untuk memasukkan data sesuai dengan kategori dan menghindari overlap (tumpang tindih) antara satu unit data dan yang lainnya dengan cara memberikan kode peristiwa, struktur sosial dan metode ${ }^{7}$.

\footnotetext{
${ }^{5}$ Lihat, (Moleong, $2004:$ 4).

${ }^{6}$ Sudarwan Danim, Ibid, hal : 110.

${ }^{7}$ Sudarwan Danim, ibid, hal : 227
} 
Berdasarkan uraian tersebut diatas penyajian data dilakukan dalam bentuk deskriptif yaitu data diuraikan dalam kalimat-kalimat sehingga membentuk suatu pengertian berhubungan dengan masalah yang diteliti sesuai kaidah akademik. Disajikan secara sistematis dan teratur yang memuat interelasi relevansi fakta dengan lengkap dalam area permasalahan dan disimpulkan menurut ruang lingkup generalisasi sesuai dengan justifikasi data yang telah disajikan dengan menggunakan pisau analisis yang ada untuk mendapatkan hasil analisis yang obyektif.

\section{Merangkai Butiran Permata : Sejarah dan Perkembangan Komunikasi dalam Veda}

Sejarah peradaban manusia telah memberikan catatan yang sangat penting kepada manusia bahwa manusia dikatakan sebagai penentu keharmonisan dunia. Keberadan manusia ini memberikan dampak yang sangat signifikan dalam kehidupan ini, tentunya dengan usaha nyata walaupun dengan perbuatan yang sangat sederhana. Walaupun hal yang sangat sederhana hasil perbuatan manusia ini selalu dikenang sebagai buah pikiran yang membawa pengaruh terhadap kehidupan manusia lainnya. Perjalanan ini menunjukan pengaruh yang sangat penting meskipun dilakukan dengan cara yang paling sederhana, minimal dengan memberikan vibrasi positif terhadap orang terdekat. Kata manusia berasal dari kata manu (Sansekerta) atau mens (Latin) yang berarti berpikir, berakal budi, atau homo (Latin) yang berarti manusia. Istilah individu berasal dari bahasa Latin, yaitu individum, yang artinya sesuatu yang tidak dapat dibagi-bagi lagi atau suatu kesatuan yang terkecil dan terbatas. Kemudian pada perkembangannya menjadi menjadi homo longuens (makhluk yang berbicara) yang dalam hal ini berarti segala pemikirannya disampaikan melalui bahasa kepada manusia lainnya ${ }^{8}$.

Secara kodrati, manusia merupakan makhluk monodualis. Artinya selain sebagai makhluk individu, manusia berperan juga sebagai makhluk sosial yang selalu bermasyarakat ${ }^{9}$. Sebagai makhluk individu, manusia merupakan makhluk ciptaan Tuhan yang terdiri atas unsur jasmani (raga) dan rohani (jiwa) yang tidak dapat dipisahkan. Jiwa dan raga inilah yang membentuk individu. Manusia juga diberi kemampuan (akal, pikiran, dan perasaan) sehingga sanggup berdiri sendiri 
dan bertanggung jawab atas dirinya. Disadari atau tidak, setiap manusia senantiasa akan berusaha mengembangkan kemampuan pribadinya guna memenuhi hakikat individualitasnya (dalam memenuhi berbagai kebutuhan hidupnya). Hal terpenting yang membedakan manusia dengan makhluk lainnya adalah bahwa manusia dilengkapi dengan akal pikiran, perasaan dan keyakinan untuk mempertinggi kualitas hidupnya.

Perkembangan peristiwa tutur atau yang dalam perkembangan modern menjadi interaksi atau komunikasi menjadi cabang ilmu yang menarik untuk dikaji secara aspek keilmuan apalagi dikaitkan dengan permasalahan agama dan budaya. Secara aspek sejarah bahwa di negara Yunani dikenal sebagai negara yang telah mengembangkan seni retorika yang dipelopori oleh Georgias (480-370 SM) yang dianggap sebagai guru retorika pertama bagi sejarah umat manusia ${ }^{10}$. Berkembang kemudian di Romawi ada seorang tokoh yang bernama marcus Tulius Cicero (106-43 SM) yang dikenal sebagai tokoh orator pada susunan pidatonya Cicero menggunakan sistematika pendahuluan, pemaparan, peneguhan, pertimbangan dan penutup. Pada isi pidato ini kemudian dikembangkan lagi oleh kaisar Romawi yang bernama Julius Caesar (100-44 SM) yang dikemas dalam bentuk pengumuman yang dimaksudkan agar seluruh berita dan kegiatan politik diketahui oleh rakyatnya. Perkembangan yang menakjubkan lainnya ketika pada $105 \mathrm{M}$ diketemukannya kertas oleh bangsa Cina untuk menuliskan berbagai berita yang kemudian digunakan sampai sekarang ${ }^{11}$.

Pada pembahasan ini menunjukan tentang perjalanan yang ada dalam peradaban Veda yang pada pembahasan pertama yang harus diketahui adalah tentang sejarah Veda. Secara bukti arkeologi menunjukan bahwa budaya Veda sudah berjalan jauh didirikan oleh orang nomadik yang memiliki kulit terang yang telah menyerang India sekitar 1500-100 SM. Akan tetapi, jauh sebelum itu menunjukan bahwa Rg Veda sebagai kitab yang sangat tua dalam peradaban manusia mengacu pada bintang pada 6000-7000 SM yang merupakan lanjutan dari peradaban prasejarah yang ada dalam kebudayaan India di lembah Indus ${ }^{12}$.

\footnotetext{
${ }^{10}$ Nurani Soyomukti, Pengantar Ilmu Komunikasi (Yogyakarta : Arruzz media, 2012), hal : 13. Gagasan ini pertama kali dikembangkan oleh kaum Sofis yang pada saat itu Yunani sedang mengembangkan kedemokrasiannya untuk itulah muncul seni berpidato untuk mewarnai proses politik demokrasi tersebut.

${ }^{11}$ Nurani Soyomukti, Ibid, hal : 17.

${ }^{12}$ Bansi Pandit. Pemikiran Hindu : Pokok-Pokok Pemikiran Hindu Dan Filsafat (Surabaya : Paramita, 2006), hal : 368-369.
} 
Penjelasan lain menunjukan bahwa Veda yang sudah sangat tua ini mengalami perjalanan waktu yang sangat panjang, hal ini pula banyak ahli sejarah Hindu yang menafsirkan waktu Veda itu diturunkan. Hal ini misalnya dijelaskan oleh Vidyaranya yang menafsirkan Veda diturunkan 15.000 SM, Lokamaya Tilak Sastri 6000 SM dan yang paling muda dijelaskan oleh sarjana luar Stutterheim 1000-500 SM. Veda inilah yang kemudian ditulis kembali oleh Maharsi Vyasa yang kemudian dibantu oleh muridnya yang bernama Sumantu, jaimini, Pulaha, dan Vaisampayana ${ }^{13}$.

Sejarah dan perspektif komunikasi dalam Veda inilah yang menjadikan pembauran yang sangat penting dalam perkembangan agama Hindu pada masa kini dan akan datang. Keunikan ajaran sanatana dharma yang dikembangkan dalam kebudayaan yang berbeda dalam bangsa yang berbeda pula menjadikan Veda ini mampu untuk mengikuti kearifan lokal yang ada. Secara lingkup sejarah bahwa Veda sudah dikembangkan oleh para maharsi yang diterima dengan ajaran spiritual dalam kurun waktu yang berjenjang. Wujud kearifan lokal yang memperlihatkan sifat Veda yang fleksibel adalah mampu untuk menghidupkan budaya setempat dan menjadikan budaya itu tumbuh dan berkembang mengikuti perkembangan jaman yang ada. Bukan yang dalam hal ini mematikan budaya setempat dan menggantikan budaya yang baru, keadaan inilah yang menjadikan budaya Veda mampu untuk berakulturasi dengan budaya lokal yang ada. Perspektif agama Hindu jika dilihat dalam kaca mata budaya, khususnya yang ada di Indonesia justru menjadikan budaya lokal dapat tumbuh dengan baik dan menjadikan budaya asli dapat tetap eksis. Keaslian budaya asli inilah yang menjadikan Hindu mudah diterima oleh berbagai daerah yang ada di Nusantara baik itu dari ruang adat, istiadat, bahasa, ras dan faktor lain yang mendukung keberadaan komunikasi antarbudaya dalam Hindu itu sendiri.

Komunikasi antarbudaya, Lustig and Koester's menyatakan (2003: 4951), adalah sebuah "proses simbolik yang mana orang dari budaya-budaya yang berbeda menciptakan pertukaran arti". Hal tersebut terjadi "ketika perbedaanperbedaan budaya yang besar dan penting menciptakan interpretasi dan harapanharapan yang tidak sama mengenai bagaimana berkomunikasi secara baik”. Jandt

${ }^{13}$ I Made Titib, Veda Sabda Suci : Pedoman Praktis Dalam Kehidupan Manusia (Surabaya : Paramita, 2003), hal : 43-44 
(2004: 4) mengatakan komunikasi antarbudaya tidak hanya komunikasi antar individu tapi juga di antara "kelompok-kelompok dengan identifikasi budaya yang tersebar'. Ringkasnya, komunikasi antarbudaya menjelaskan interaksi antar individu dan kelompok-kelompok yang memiliki persepsi yang berbeda dalam perilaku komunikasi dan perbedaan dalam interpretasi. Beberapa studi mengenai komunikasi antarbudaya menguji apa yang terjadi dalam kontak dan interaksi antarbudaya ketika proses komunikasi mencakup orang-orang yang secara budaya tersebar (Samovar \& Porter 1997).

Sebuah permasalahan yang sama dalam komunikasi antarbudaya muncul "ketika orang-orang yang menjelaskan dirinya sebagai kelompok yang berbangsa dan beretnis sama tidak mau melakukan pertukaran ide-ide mengenai bagaimana menunjukkan identitas mereka dan tidak menyetujui tentang norma-norma untuk interaksi" (Collier 1997: 43). Untuk mencapai komunikasi antarbudaya yang efektif, individu seharusnya mengembangkan kompetensi antarbudaya; merujuk pada keterampilan yang dibutuhkan untuk mencapai komunikasi antarbudaya yang efektif. Jandt $(1998,2004)$ mengidentifikasikan empat keterampilan sebagai bagian dari kompetensi antarbudaya, yaitu personality strength, communication skills, psychological adjustment and cultural awareness.

McLuhan (dalam Infante et.al, 1990 : 371) menyatakan bahwa dunia saat ini telah menjadi "Global Village" yang mana kita mengetahui orang dan peristiwa yang terjadi di negara lain hampir sama seperti layaknya seorang warga negara dalam sebuah desa kecil yang menjadi tetangga negara-negara lainnya. Perubahan sosial lain yang berpengaruh dalam komunikasi antar budaya adalah dengan makin banyaknya perayaan-perayaaan budaya sebuah etnis dalam sebuah negara. Perbedaan budaya dalam sebuah negara menciptakan keanekaragaman pengalaman, nilai, dan cara memandang dunia. Keanekaragaman tersebut menciptakan pola-pola komunikasi yang sama di antara anggota-anggota yang memiliki latar belakang sama dan mempengaruhi komunikasi di antara anggotaanggota daerah dan etnis yang berbeda.

Proses pertukaran antarbudaya ini menunjukan tentang perkembangan yang sangat pesat dalam bidang komunikasi, sehingga proses komunikasi ini tidak ada halangan yang terikat oleh ruang dan waktu. Hal yang sama juga terjadi ketika Veda disebarkan dengan jalur damai dan halus dengan mengikuti dinamika 
kearifan lokal yang ada. Pertukaran budaya yang ada menjadikan pola untuk berkomunikasi dengan budaya, bahasa dan tentunya latar belakang sosial yang berbeda pula menjadikan pertukaran budaya antara India dengan Indonesia menjadikan negara yang saling melengkapi dalam konteks hubungan kenegaraan. Melihat kemajuan perkembangan tentang sistem kepercayaan kuno yang ada di Nusantara dengan adanya animisme dan dinamisme, kemudian datangnya kebudayaan India yang dibawa oleh para pedagang, kaum brahmana untuk menjalankan tugasnya menjadikan kedua negara dengan latar belakang budaya saling melengkapi.

Wujud komunikasi yang aktual juga dijelaskan dalam hubungan yang saling bersinergi antara perkembangan pendidikan yang dirintis oleh Tagore dengan Ki Hajar Dewantara. Sementara itu kedekatan diantara kedua tokoh, masing-masing Rabindranath Tagore (1861-1941) dari Shanti Niketan dengan Ki Hadjar Dewantara (1889-1959) dari Taman siswa, merupakan bukti sejarah yang menunjukkan bahwa diantara Shanti Niketan dengan Taman siswa telah lama terjalin hubungan yang dekat dalam rangka pengembangan sistem pendidikannya.

Manusia adalah ciptaan Tuhan dengan derajat paling tinggi di antara ciptaan-ciptaan yang lain. Untuk itulah dalam penggolongan makhluk hidup dijelaskan dalam konsep Tri Pramana yaitu sabda, bayu dan idep. Pada tataran kehidupan tumbuhan hanya mempunyai bayu (daya untuk bergerak), hewan hanya mempunyai sabda (berbicara) dan bayu. Sedangkan manusia adalah makhluk yang mempunyai kelengkapan yang sangat lengkap yang disebut dengan tri pramana, kelengkapan ini karena manusia dibekali dengan pikiran (idep) dalam melakukan segala perbuatannya di dunia ini. Hewan masih menggunakan nalurinya untuk melakukan pekerjaannya baik itu untuk melakukan kegiatan seksualitas dan gerak. Dan tumbuhan hanya terbatas gerakannya yaitu mengikuti arah matahari dan campur tangan manusia dalam memperlakukannya.

Banyak orang beranggapan bahwa dalam sebuah pembicaraan, kita harus menggunakan etika untuk menghargai dan menghormati lawan bicara. Ada sebuah teori yang mendefinisikan etika sebagai, "sebuah cabang ilmu filsafat yang berbicara mengenai nilai dan norma, moral yang menentukan perilaku manusia dalam hidupnya". Dalam teori ini, etika memiliki 3 tujuan, yaitu:Membantu manusia untuk bertindak secara bebas dan dapat dipertanggung jawabkan, 
membantu manusia mengambil sikap dan tindakan secara tepat dalam hidup ini dan tujuan akhir untuk menciptakan kebahagiaan. Terlepas setuju atau tidaknya kita dengan teori diatas, namun ada hal yang bisa kita sepakati bahwa etika berhubungan dengan moral.

Melanjutkan pembahasan sebelumnya tentang keutamaan manusia dalam kehidupan yang dinilai melebihi dari makhluk yang lainnya. Kehadiran manusia di dunia ini sebagai sesuatu hal yang mempunyai misi baik itu untuk pribadi maupun dalam lingkup yang luas. Secara pribadi bahwa merupakan buah karma pada kehidupan masa lalu (karma wasana), sehingga pada kehidupan ini orang tersebut dapat menikmatinya. Buah dari karma itu jika dahulu yang dikerjakan baik maka hasilnya juga baik, namun sebaliknya jika kejahatan yang dilakukan maka hasilnya adalah kesengsaraan. Oleh karena itulah dalam Hindu dikenal dengan kelahiran surga dan kelahiran neraka. Adapun ciri dari kelahiran surga adalah seseorang yang mempunyai kemuliaan dalam kehidupan dan kelahiran neraka adalah sebaliknya yaitu orang yang dalam hidupnya selalu mendapatkan kesusahan dan kesengsaraan hidup.

Pandangan yang parsial banyak mengusung pemikiran bahwa karma adalah yang berkaitan dengan kesengsaraan dan kebaikan tidak termasuk dalam karma. Selain itu, bahwa kehidupan sangat mendambakan surga dan terkait dengan tempat yang sangat menyeramkan yang bernama neraka. Pandangan ini tentunya sangat bertentangan dengan agama Hindu bahwa yang dimaksud dengan karma adalah segala sesuatu yang mendatangkan hasil baik maupun buruk dari segala sesuatu yang kita kerjakan. Pemahaman karma yang ada pada agama Hindu membawa pengertian yang sangat dalam bahwa segala sesuatu pasti mendatangkan phala (hasil).

\section{E. Etika Komunikasi dalam Veda}

Secara konsep menunjukan bahwa kedudukan komunikasi menunjukan posisi yang sangat vital. Hal ini dibuktikan tentang pengendalian berbicara yang terdiri dari tidak mencaci maki, tidak berkata kasar, tidak memfitnah, dan tidak ingkar janji. Akan tetapi melihat keadaan sekarang ini banyak perbuatan yang dinilai telah melanggar etika dalam berkomunikasi baik dalam lingkup sosial maupun dalam rumpun etika religius yang disebabkan oleh berbagai faktor. Oleh 
karena itulah, peristiwa tutur yang dilakukan oleh seseorang dapat dengan mudah untuk menurunkan harga diri seseorang dan menaikan harkat diri seseorang.

Penjelasan ini sebagaimana yang telah banyak dibicarakan oleh banyak ahli aliran linguistik Noam Chomsky (1957) yang dalam pembahasannya mengemukakan bahwa bahasa mempunyai dua aspek yang disebut dengan ; struktur batin dan lahir ${ }^{14}$. Hal ini menunjukan bahwa dampak dari berbicara mengandung konsekuensi yang sangat besar baik untuk diri seseorang yang berbicara maupun bagi orang lain yang mendengarkan. Dampak yang sangat luas ini mengindikasikan bahwa kekuatan suara yang dikemukakan oleh seseorang mampu untuk menjadikan orang yang ada disekitarnya dapat terpengaruh dengan sangat mudah dan dampak yang sangat menyedihkan adalah adanya kasus pelanggaran yang menyangkut SARA.

\section{Manacika}

Merupakan buah pikiran yang dimiliki oleh seseorang. Pikiran merupakan hal utama yang dimiliki oleh manusia, karena manusia selain pikiran dilengkapi dengan sabda dan bayu. Keutaman pikiran sangatlah istimewa karena bisa menghantarkan seseorang pada tingkat yang lebih tinggi maupun pada lembah kesengsaraan. Akan mendapatkan pada tingkat yang lebih tinggi ketika pikiran digunakan untuk hal-hal yang kebaikan dan sebaliknya ketika pikiran diarahkan pada hal keburukan akan mendapatkan lembah kesengsaraan.

Pada ilmu yoga yang merupakan salah satu cabang dari filsafat Hindu ${ }^{15}$ menerangkan bahwa yoga merupakan cabang ilmu pengetahuan yang mempelajari tentang pengendalian pikiran yang didalamnya terdapat delapan tahapan untuk mencapai kesadaran tertinggi. Untuk menempuh jalan ini orang harus sabar dan tekun serta tujuan utamanya adalah untuk mencapai kesadaran yang universal yang artinya adalah memekarkan nilai cinta kasih kepada seluruh makhluk hidup.

${ }^{14}$ I Wayan Jendra. Berbicara dalam Sastra Hindu. Jakarta : Pustaka Manikgeni, 1993, hal :62

${ }^{15}$ I Wayan Maswinara. Sistem Filsafat Hindu (Surabaya : Paramita, 1999), Hal : 164. Filsafat yoga ini cabang dari sad darsana yang didirikan oleh maharsi Patanjali. Untuk mencapai tahapan ini harus melewati astanga yoya atau delapan anggota yoga yang terdiri dari ; yama, nyama, asana, pranayama, pratyahara, dharana, dyana dan samadhi. Delapan tahapan ini harus dilaksanakan bertahap. 


\section{Wacika}

Sebagai ucapan atau lisan digunakan untuk menginformasikan suatu pesan kepada orang lain. Terkadang dengan pesan inipula seseorang terbawa dalam arus yang sangat pelik untuk dilakukan karena terhadang oleh dilema antara diucapkan dan didiamkan. Pada kehidupan sehari-hari peranan mulut sebagai organ manusia ini sangat penting sekali. Manfaat mulut ini mendapat kedudukan yang terhormat dalam tubuh manusia karena selain untuk berbicara, juga terdapat keistimewaan lain seperti, makan, minum, bernyanyi dan sebagai komunikasi dalam kehidupan. Hal ini dijelaskan dalam Bhagavadgita 17.15 yang dijelaskan bahwa :

Anudvega karai் vākyam satyam priya hitam ca yat svadhyāyabhyasanaì caiva vān்-mayam tapa ucyate Terjemahan :

Pertapaan suara terdiri dari mengeluarkan kata-kata jujur, menyenangkan, bermanfaat, dan tidak mengganggu orang lain, dan juga membacakan susastra Veda secara teratur ${ }^{16}$.

Terkadang dalam hidup ini kita sering lupa bahwa seandainya kita tidak mempunyai mulut bagaimana kita dapat berkomunikasi dengan orang lain. Atau seandaainya kita sedang sakit mulut, untuk makan atau mengunyah makanan saja sangat sulit apalagi untuk berbicara. Selain itu, ketika kita bercermin dalam bayangan cermin itu terlihat mata ada dua, telinga ada dua, lubang hidung ada satu, tetapi mulut kita satu. Jika hal ini kita tarik pada kesimpulan bahwa dalam hidup ini kita harus berhati-hati dalam menggunakan mulut. Oleh karena itu dijelaskan dalam Nitisastra, Sargah V. bait 3 bahwa :

Wasita nimitanta manemu laksmi, wasita nimitanta pati kapangguh, wasita nimitanta manemu duhka, wasita nimitanta manemu mitra

Terjemahan :

Karena berbicara engkau menemukan kebahagiaan, karena berbicara engkau mendapat kematian, karena berbicara engkau akan menemukan

${ }^{16}$ Sri Srimad AC. Bhaktivedanta Swami Prabhupada, Bhagavadgita Menurut Aslinya, (Jakarta : The Bhakti Vedanta Book Trust, 2006), hal : 777. 
kesusahan, dan karena berbicara pula engkau mendapat sahabat ${ }^{17}$.

Pembahasan ini mengingatkan penulis ketika berbincang dengan salah seorang sahabat bahwa pada kehidupan setelah kematian semua organ tubuh kita diberikan kesempatan untuk berbicara mulai dari kaki sampai dengan ujung kepala. Tetapi dari semuanya itu hanya ada satu organ yang tidak bisa berbicara yaitu mulut. Ketika penulis bertanya mengapa tidak dapat berbicara, jawaban dia adalah "karena pada saat itu mulut tidak diberikan haknya untuk berbicara seperti keadaannya di dunia tetapi mulut itu di kunci dan gilirannya organ lain untuk berbicara". Oleh karena itu, pada pembahasan ini penulis hanya menghantarkan pembaca untuk menyelami bahwa peranan wacika sangat penting yaitu untuk berkomunikasi dalam kehidupan agar digunakan dengan sebaik-baiknya. Pembahasan ini akan lebih detail pada bab selanjutnya.

Penggambaran tentang wicara merupakan hal yang sangat penting karena menyangkut seluruh aspek kehidupan. Untuk itulah Ben Jonson mengatakan bahwa "bahasa adalah yang paling memperlihatkan manusia, berbicaralah supaya aku dapat mengetahuinya" ${ }^{\prime 18}$. Konsep berbahasa ini sebagai suatu hal yang sangat penting, karena menandakan bahwa seseorang yang mahir dalam berbahasa menandakan keluasan pengetahuan dan wawasan orang tersebut. Namun sebaliknya bahwa orang yang pendiam sagat susah sekali untuk menjelaskan tentang pengetahuan yang dia miliki, sehingga sangat sulit mengukur pengetahuan orang tersebut. Kedudukan berbicara dalam agama Hindu yang sangat penting harus mematuhi etika yang berlaku. Untuk hal ini Bhagavan Satya Narayana memaparkan tentang cara pengendalian berbicara yang meliputi bahwa : "Lidahmu bertanggungjawab pada empat kesalahan besar bahwa ; berdusta, membicarakan kesalahan orang, mencaci maki dan berbicara tidak susila. Keempat kesalahan ini harus dihindari jika santih harus ada dalam pribadi sendiri atau didalam pergaulan bermasyarakat" 19 .

Melanjutkan pembahasan ini menunjukan bahwa proses berbicara ini mendapatkan tempat yang sangat istimewa bahwa segala apa yang didapatkan di

\footnotetext{
${ }^{17}$ Darmayasa. Nitisastra (Denpasar : Manikgeni, 2001), hal : 24.

${ }^{18}$ I Wayan Jendra. Berbicara Dalam Sastra Hindu, (Jakarta : Manikgeni, 1993), Hal : 33. Tulisan Ini Diadopsi dari tulisan Pei 1971 dengan judul Kisah daripada Bahasa (terjemahan dari The Story Of Language olehh Nugroho Notosoesanto, jakarta : Bharata, Halaman 181.

${ }^{19}$ I Wayan Jendra, Ibid, hal : 51. Tulisan ini diambil dari itulisan Murniada Brotherhood Sai Awatar I, 1988 : 10 dan Bd Sai Awatar II, $1988: 19)$.
} 
dunia ini diperoleh melalui perkataan dan sampai pada akhir hayatnya juga mendekati manusia melalui kata-kata. Untuk itu pula bahwa berbicara adalah sebuah proses pendewasaan diri bagi diri seseorang, hal lain juga diungkapkan oleh para Rsi ketika mendapatkan wahyu yang dijelaskan dalam kitab Rg Veda X. 71.1.2 bahwa :

Wicara utama oh Brhaspati, yang diucapkan oleh orang-orang suci, menyebut namany. Wicara mereka mulia, tiada noda. Dengan cinta kasih (prema) mengungkapkan yang maha suci dan mereka mengucapkan katakata itu, tersaing dalam batin seperti ; mereka yang mengayak tepung dalam ayakan. Disitulah terjadi ikatan persahabatan dalam wicara itulah terkandung keindahan ${ }^{20}$.

Bersandar dari sloka tersebut menunjukan bahwa uraian tentang proses berbicara sungguh sangat mengagumkan bahwa untuk mencapai hal yang tinggi diperlukan proses belajar dan berlatih. Hal ini juga diperjelas dalam slokantara sloka 69 yang menyatakan bahwa :

Kalinganya lima ikang tan amuhara papa ning lenok lwirnya kawruhana ujar ing siwo mapaceh-pacehan karakshan ing hurip karaksahan ing drewya, karaksahan ing anak rabi, muwah ri sedeng ing pasanggaman wenang lenok ing mangkana

Terjemahan :

Ada lima macam kebohongan yang dapat dianggap bukan dosa yaitu : lelucon, ucapan yang menyebabkan orang tertawa, ucapan untuk menyelamatkan jiwa, ucapan untuk menyelamatkan harta kekayaan, menyelamatkan anak dan istri, dan juga pada waktu bersenggama atau bercumbu rayu, kalau ucapan itu bohong, kebohongan itu dibolehkan ${ }^{21}$.

Hal ini menandakan bahwa perbuatan yang ada termasuk dalam perbuatan yang dibenarkan. Dalam konteks sosial dalam sastra agama Hindu terdapat lima kebohongan yang dapat dianggap salah akan tetapi, hal ini dapat digolongkan menjadi kebenaran. Hal ini kemudian dipertegas dalam Sarasamuccaya 134

\footnotetext{
${ }^{20}$ I Wayan Jendra, Ibid, hal : 57.

${ }^{21}$ Tjok Rai Sudharta, Slokantara : Untaian Ajaran Etika, Teks, Terjemahan Dan Ulasan, (Surabaya : Paramita, 2003), hal : 228-229.
} 
dijelaskan bahwa "bicara yang tidak benar belum tentu bohong, sebab menimbulkan kebaikan satya juga namanya, bicara yang benar jika menimbulkan yang kurang menyenangkan dinamakan dusta"22. Untuk kemudian kebenaran yang dilakukan dengan berbohong ini tergolong dalam panca nrta yang dalam hal ini mencakup kebohongan kepada anak, istri, musuh, perdagangan, dan kepada orang sakit. Dari lima kebohongan inilah yang dalam Veda diperbolehkan karena masuk dalam perbuatan yang dibenarkan.

\section{Kayika}

Kayika diartikan adalah perbuatan yang dalam hal ini biasanya sering dikaitkan erat dengan karma atau berbuat. Perbuatan yang dikerjakan pada kehidupan ini dalam ajaran Hindu membawa pengaruh kepada hidup ini baik itu secara langsung maupun tidak langsung. Secara langsung misalnya, akan mendapatkan sesuatu yang langsung diterima dalam kehidupan ini. Kemudian yang diterima tidak langsung adalah kemungkinan akan diterima pada kehidupan yang akan datang. Perbuatan seseorang pada kehidupan ini mencerminkan akal budi dan kepribadian seseorang dalam kehidupan ini. Di tengah era globalisasi menuntut untuk setiap insan harus meningkatkan kemampuan secara nyata dalam segi kehidupan, untuk meningkatkan kemampuan inilah selalu dibarengi dengan akal dan nurani agar tidak melanggar norma-norma kemanusiaan. Akan tetapi melihat fakta sekarang ini sungguh sangat miris, ketika individu yang dalam memenuhi kebutuhan ini mereka terdorong sifat serakah baik itu pada harta atau jabatan dan mementingkan sendiri serta kelompoknya.

\section{Parahyangan}

Merupakan hubungan antara manusia dengan pencipta-Nya ${ }^{23}$. Untuk itulah, proses hubungan antara pemuja dan yang dipuja saling berkaitan. Ketika dikaitkan dengan bangunan suci Pura bahwa parahyagan merupakan areal pura yang berada pada bagian utama (uttama mandala), kawasan ini memiliki bangunan suci untuk melakukan pemujaan kepada Tuhan yang dikenal dengan Padmasana. Pada awalnya konteks pembicaraan tentang hubungan antara manusia dengan Tuhan sudah ada pada jaman purbakala yang digambarkan dengan bentuk interaksi pada roh suci. Hal ini kemudian, berkembang dalam bentuk aliran animisme dan

\footnotetext{
${ }^{22}$ Nyoman kajeng, Sarasamuccaya, (Denpasar : Paramitha, 2003), hal : 57.

${ }^{23}$ I Gede Jaman, Tri Hita Karana Dalam Konsep Hindu, (Denpasar : Bali Pos, 2007), hal : 20.
} 
dinamisme yang lebih mendominasi pada kepercayaan masyarakat. Kemudian, pada pemujaannya yang ada di Nusantara berkembang dalam bentuk agama yang bermula dari agama Hindu dan disusul oleh Budha. Agama Hindu merupakan agama yang tertua ada di Nusantara yang dikenal dengan pemujaan kepada Siva yang lebih kental dengan pemujaan kepada lingga ${ }^{24}$.

Penggambaran tentang lingga selalu dikaitan dengan adanya gunung dan yoni sebagai danau atau perairan, karena hal ini merupakan simbol dari kemakmuran dan kesejahteraan. Adanya gunung Semeru sebagai gunung tertinggi di Pulau Jawa, keyakinan akan semakin tinggi suatu tempat semakin suci, dibuktikan dengan perkembangan masa prasejarah sampai masa klasik Semeru sebagai tempat pemujaan bagi arwah nenek moyang yang berastana di tempat tertinggi dan tempat bagi para pendeta untuk belajar spiritual serta kanuragan dalam penempahan diri. Dalam perkembangan Hindu Gunung Semeru adalah simbol pemujaan Sang Hyang Acalapati yang merupakan Dewa Gunung atau Semeru merupakan astana bagi Dewa Siwa.

Hindu Aliran Siwa mayoritas diyakini sebagian besar masyarakat masa klasik berhubungan dengan Gunung Semeru merupakan Gunung yang sangat aktif. Karena diyakini Dewa Siwa adalah Dewa pelebur, sehingga masyarakat ketika itu meyakini kemarahan Dewa Siwa akan perilaku manusia apabila Gunung Semeru meletus. Persembahan bagi Dewa Siwa ketika itu sangatlah penting dan merupakan kewajiban bagi penganutnya. Selain sebagai Dewa pelebur bagi penganutnya Dewa Siwa dianggap dewa yang memberikan berkahnya karena dari letusan Gunung tersebut keluar material-material yang menyuburkan dan menghasilkan tambang pasir bagi masyarakat sekitarnya. Dalam kepercayaan di india bahwa sri Sankaracarya merupakan avatara dari Siva yang menganut filsafat Adwaita yang memuja tentang adanya Siva yang utama atau brahman sebagai satu-satunya entitas yang utama (Titib, 1994 : 69).

Berbagai literatur suci yang tergolong Weda dengan tegas menyebutkan bahwa lingga sebagai simbol brahman, tuhan yang maha esa dengan aksara dan suara "aum" yang bergema menciptakan pertiwi atau yoni, alam semesta langit

${ }^{24}$ Untung Suhardi. Kajian Bentuk Dan Makna Nilai Filosofis Lingga Dalam Perspektif Ajaran Hindu (Studi Pemujaan Lingga Di Desa Linggoasri, Kecamatan Kajen, Kabupaten Pekalongan - Jawa Tengah). Denpasar: IHDN, 2013, (tidak diterbitkan), hal : 6. 
dan bumi dengan segala ciptaan-Nya. Menyimak dari uraian ini bahwa lingga sebagai sesuatu yang sakral. Lingga-Yoni sebagai simbol/lambang alat reproduksi lelaki dan perempuan (pallus atau vagina): Kamus; Jawa Kuna Indonesia mendefinisikan: "Linga (skt) tanda, ciri, isyarat, sifat khas, bukti keterangan, petunjuk; Lingga, lambang kemaluan lelaki (terutama Lingga Siwa dibentuk tiang batu), patung dewa, titik tugu pemujaan, titik pusat, pusat poros, sumbu". "Yoni (skt) rahim, tempat lahir, asal Brahmana, Daitya, dewa, garbha, padma, naga, raksasa, sarwa, sarwa batha, sudra, siwa, widyadhara dan ayonia (P.J. Zoetmneder, S.C. Robsou, 1994: 601). Ensiklopedia Indonesia memberi definisi: "Lingga, dalam mithologi Hindu : alat kelamin pria (lat : phallus, lambang siwa sebagai dewa semesta, kebalikan dengan Yoni. "Yoni, alat kelamin kemaluan perempuan sebagai tara atau timbalan dan Linggam merupakan lambang syakti atau prakrti yang dijabarkan dalam bentuk unsur kewanitaan " (Ensiklopedia Indonesia Ikhtisar Baru Van Hove, Jakarta 1990, 2020 dan 3993).

Selanjutnya Shanta Nair (2009: 73) mengatakan bahwa "The Siva lingam represent lord Siva, the mahayogi, the Sarveshvara, the supreme powe that has no begining and end. It is also symbol of para brahman”. Hal senada juga diungkapkan bahwa lingga merupakan simbol energi generatif. Menyebut ini sebagai "phallic worship" (pemujaan palus) adalah salah secara total memahami representasi secara miniatur atau bentuk simbolik, menciptakan dan melepaskan kekuatan dengan mana dia diasosiasikan." Ada perbedaan sangat mendasar antara dua definisi pertama dengan dua definisi terakhir. Lingga sebagai simbol Ayah (Tuhan) dan Yoni sebagai Ibu (pertiwi), sebagai alam semesta, telah dipuja oleh umat Hindu sejak 3.500 tahun sebelum masehi. Lingga dan Yoni diwujudkan menjadi tempat suci atau bangunan suci dalam bentuk arca pelinggih, candi, seperti bangunan Padmasana yang kita kenal sekarang.

Dapat ditambahkan, seorang tokoh intelektual Hindu Swami Harshananda ketika berada di Sri Ramakrishna Ashrama menyebutkan Lingga dan Yoni sebagai Simbol Tuhan God dan umat Hindu yang universal : Secara literal Siva artinya keberuntungan dan Lingga artinya satu tanda atau satu simbol. Dari sini Sivalingga adalah satu simbol Tuhan yang agung dan semesta yang sepenuhnya adalah keberuntungan. Siva juga berarti Yang Esa yang di dalamnya seluruh ciptaan istirahat setelah mahapralaya. Liñgga juga berarti hal sama di mana 
obyek-obyek ciptaan dipralina selama disintegrasi dan semesta ciptaan. Karena, menurut agama Hindu, adalah Tuhan yang sama yang menciptakan, memelihara dan menarik alam semesta ke dalam dirinya. Maka Sivaliñgga merepresentasikan Tuhan sendiri secara simbolik. (Swami Harshananda, 1978:7).

Selanjutnya, pemujaan lingga merupakan sebuah simbol yang mempunyai makna filosofis yang sangat dalam bahwa lingga yoni merupakan sebuah pemujaan kuno yang menggambarkan adanya lambang yang menggambarkan tentang kesuburan dan kesejahteraan. Selanjutnya dalam ajaran tantra mengatakan bahwa ada berupa lima sadhana yang disebut panca makara (madira, mastsya, mamsa, mudra dan maithuna.) dan maithuna ini merupakan hubungan seksual yang disublimasikan sebagai energi ilahi untuk menuju puncak spiritual, sehingga dalam pandangan ini seorang perempuan harus sebagai sakti dan laki-laki sebagai Siva sehingga dalam melaksanakan kegiatan seksual tidak hanya kenikmatan seksual (bhoga) tetapi sebagai ekspresi cinta kasih. Dalam pandangan tantrisme bahwa energi seksual dilambangkan dengan kundalini yang bersemayam di Mulandhara cakra, sehingga dengan dorongan energi seksual ini gerakan halus dari energi ini akan melalui cakra dan akhirnya terjadi penyatuan dengan Siva dalam sahasrara cakra (Putu Suamba, 2007 : 262-263). Jadi penyatuaan antara sakti dengan siva inilah menggambarkan penyatuan energi untuk menuju tingkat ketuhanan. Sejalan dengan pemikiran ini bahwa Koentjaraningrat menerangkan bahwa dalam banyak religi didunia tokoh dewa demikian memiliki watak dualis, artinya dapat membawa kebaikan atau kebahagiaan dan juga kejahatan atau bencana karena mempunyai kekuatan luar biasa sehingga menimbulkan sikap takut bercampur percaya (Baal, 1971 : 81 dalam Koentjaraningrat, 1987 : 79-80).

Dunia yang luas dari wujud yang tidak terhitung jumlahnya adalah Linga dari Tuhan Mahakuasa. Siva Linga adalah simbol Tuhan Siva ketika anda melihat pada Linga, pikiran adalah seketika naik dan kita mulai berpikir tentang Siva. Tuhan Siva sesungguhnya tidak berwujud. Ia tidak memiliki wujud dari dirinya walaupun semua wujud-Nya. Semua wujud adalah diresapi oleh Tuhan Siva ada kekuatan misterius Sakti yang tidak dapat dilukiskan di dalam Linga, menyebabkan konsentrasi pikiran. Bagaikan pikiran terpusat dengan mudah pemusatan pada kristal, jadi demikian juga pikiran mencapai suatu pemusatan, ketika melihat Linga. Itu adalah sebabnya Rsi jaman dulu orang Vaskita India 
melukiskan Linga untuk dipasang di kuil Tuhan Siva.Siva Linga menjelaskan bahwa dalam melakukan pemujaan lingga terdapat bahasa keheningan yang dalam. Karena lingga ini sesungguhnya adalah satu tanpa kedua, tanpa wujud. Dan jiwa Murni atau penuh bhakti yang hanya dapat mengerti bahasa ini.

Tetapi orang yang bernafsu kebinatangan orang asing tidak murni memiliki pengertian atau kecerdasan sedikit mengatakan dengan menyakitkan bahwa adanya anggapan salah bahwa pemujaan Hindu pada phallus atau organ sex sebagai kebutuhan duniawi. Mereka adalah orang bodoh, dan tidak memiliki filosofi. Linga adalah hanya simbul luar dari keberadaan tidak berwujud sebagai Tuhan Siva yang tidak terbagi, meresapi semua, kekal, bajik selalu murni, hakekat kekekalan dari alam semesta yang luas, sebagai Penghuni-Nya, karena sesungguhnya bahwa diri paling dalam atau Atman, adalah sama dengan Brahman tertinggi sebagai kekuatan yang tidak terbatas.

Bentuk hubungan antara manusia dengan Tuhan ini sebagai awal dari hubungan yang lebih mendalam antara pemuja dengan yang dipuja. Dalam ajaran agama Hindu yang terdapat dalam Catur Purusartha dijelaskan bahwa tujuan dari kehidupan adalah bagaimana untuk menegakkan Dharma, setiap tindakan harus berdasarkan kebenaran tidak ada dharma yang lebih tinggi dari kebenaran. Dalam Bagawad Gita ${ }^{25}$ disebutkan bahwa Dharma dan Kebenaran adalah nafas kehidupan. Krisna dalam wejangannya kepada Arjuna mengatakan bahwa dimana ada Dharma, disana ada Kebajikan dan Kesucian, dimana Kewajiban dan Kebenaran dipatuhi disana ada kemenangan. Orang yang melindungi dharma akan dilindungi oleh dharma maka selalu tempuhlah kehidupan yang suci dan terhormat. Dalam zaman edan ${ }^{26}$ saat ini semua orang mengabaikan kebenaran, orang sudah menghalalkan segala cara untuk mencapai tujuan, krisis moral sudah merajalela dimana-mana, kebenaran dan keadilan sudah langka, orang sudah tidak mengenal budaya malu, semua perbuatannya dianggap sudah benar dan normal. Sebenarnya Dharma tidak pernah berubah, Dharma telah ada pada zaman dahulu,

${ }^{25}$ Prabhupada, Bhagavadgita Menurut Aslinya. (Denpasar : Hanuman Sakti, 2002). Hal : 222. Penjelasan ini ada pada Bhagavadgita 4.7 yang menegaskan bahwa Tuhan sendiri dalam manifestasinya dewa Wisnu akan turun kedunia untuk menyelamatkan kebenaran ketika kebenaran itu sudah mulai merosot.

${ }^{26}$ Pada serat Joyoboyo dikatakan bahwa sekarang ini kita sudah memasuki jaman gila (edan) yang didalamnya banyak segala rintangan dan ambisi duniawi yang merebak dari segala kalangan, tetapi peringatan dari serat tersebut adalah yang terpenting dalam hidup ini adalah kita selalu ingat dan waspada kepada segala situasi dan kondisi. 
zaman sekarang dan zaman yang akan datang, ada sepanjang zaman tetapi setiap zaman mempunyai karateristik lain dalam melakukan latihan kerohanian $(\text { spiritual })^{27}$. Untuk Kerta Yuga latihan kerohanian yang baik adalah melakukan Meditasi, untuk Treta Yuga latihan kerohanian yang baik adalah dengan melakukan Yadnya atau kurban, untuk Dwapara latihan kerohanian yang baik adalah dengan melakukan Yoga yaitu upacara pemujaan dan untuk Kali Yuga latihan kerohanian yang baik adalah dengan melakukan Nama Smarana yaitu mengulang-ngulang atau menyebut nama Tuhan yang suci. Adapun penjelasan dari masing-masing bagian caturpurusaartha dijelaskan pada uraian selanjutnya.

\section{Pawongan}

Diartikan sebagai hubungan yang harmonis antara manusia dengan sesama manusia yang lainnya ${ }^{28}$. Kebahagiaan seseorang dalam kehidupan ini tidak hanya dinilai berdasarkan atas keberadaan finansial yang dia miliki tetapi jauh dari itu bahwa kebahagiaan seseorang terletak dalam melakukan pelayanan terhadap sesamanya. Selain itu, kebahagiaan dalam konsep ini menunjukan tentang kedamaian yang didapatkan ketika didapatkan dengan kebenaran, harta yang kita dapatkan berdasarkan kebenaran untuk kemudian harta itu dipergunakan untuk hal-hal yang bermanfaat untuk diri sendiri dan orang lain serta lingkungan sekitarnya.

Melanjutkan pembicaraan diatas bahwa kebenaran jika dilukiskan bersifat abstrak karena dalam hal ini sangat bergantung dengan ruang dan waktu serta kondisi pada suatu kejadian. Hal yang paling sederhana adalah jika ada orang yang ketahuan mencuri padahal hasil curiannya adalah untuk orang miskin yang tidak mampu. Kemudian ada orang yang ingin menangkapnya maka jika kita berbicara pada konteks kebenaran secara hukum positif hendaknya orang tersebut harus diberitahukan serta kemudian dipenjarakan. Akan tetapi, jika kebenaran itu dilihat secara konteks sosial bahwa orang tersebut mencuri adalah untuk memberi makan orang miskin maka kita harus melindunginya untuk kemudian harus

${ }^{27}$ Pembagian jaman yang ada dalam Hindu terdiri dari jaman Satya, Krta, dwapara dan kaliyuga. Dan sekarang sekarang ini kita sedang berada pada jaman Kaliyuga yang berumur 432.000 dan saat ini kita baru memasuki awal dari kaliyuga sekitar 5000 tahun yang lalu dan ditandai dengan naik tahta raja Parikesit menjadi maharaja di Hastinapura. Sedangkan untuk melakukan bhaktinya ditunjukan dengan Satya yuga melakukan tapa, Treta Yuga melakukan jnana, jaman Dwapara yuga melakukan yajna dan jaman kaliyuga adalah melakukan danapunia dan mengulang nama suci Tuhan.

${ }^{28}$ I Gede Jaman, Ibid, Hal : 20 
diberikan nasehat bahwa mencuri adalah perbuatan dilarang oleh hukum dan larangan dari ajaran agama. Hal lain yang dicontohkan lagi adalah ketika terjadi perang antara Rama dengan Ravana. Pada cerita epos Ramayana ${ }^{29}$ ini bahwa sesungguhnya tokoh Ravana pada pemikiran Rama adalah salah karena telah menculik Sita sebagai istri yang sah. Namun, ketika Ravana sebagai penguasa kerajaan Alengka bagi rakyatnya adalah raja yang bijaksana karena telah memberikan kesejahteraan dan kemakmuran kepada para rakyat dan pemerintahan Alengka yang selama ini dipimpinnya.

Pemahaman kebenaran yang dimaksudkan untuk mendapatkan kebahagiaan sebenarnya memerlukan pemikiran yang mengacu pada kebenaran umum yang tidak memihak pada kepentingan indvidu atau golongan. Oleh karena itu, kebenaran pada kontek dharma adalah kebenaran yang bertujuan kepada kesadaran untuk meyakini bahwa kebahagiaan yang tertinggi adalah sebagai pelayan Tuhan dan seluruh makhluk. Hubungan antara manusia dengan sesamanya sebagai patokan bentuk interaksi sosial yang terjadi dalam kehidupan sosial kemasyarakatan.

\section{Palemahan}

Diartikan sebagai hubungan yang harmonis antara manusia dengan lingkungannya ${ }^{30}$. Hubungan manusia dengan alam, hal ini mengharuskan manusia untuk bisa memahami makna mendekatkan diri dengan alam, karena manusia tidak bisa hidup tanpa alam, yaitu makna relasi yang saling menguntungkan dan saling menjaga satu sama lain. Keseimbangan dan keharmonisan dengan sesama manusia dapat kita wujudkan dengan melakukan ngayah bersama sepanjang persiapan upacara tawur agung di pura dan membuat ogoh-ogoh. Selain tercermin dari aktivitas kebersamaan yang serempak dalam suasana saling membantu yang dilandasi dengan hati dan keramah-tamahan didalam proses selama pembuatan caru untuk Upacara Tawur. Mengawali kegiatan dengan pelaksanaan matur piuning sebagai salah satu usaha untuk mengundang pemendak rawuh dengan ngiring sungsungannya yaitu Ida Bhattara-bhattari dalam wujud pakuluh. Sedangkan keseimbangan dan keharmonisan dengan alam dapat diwujudkan melalui adanya upacara tawur yang merupakan rangkaian dan siklus

\footnotetext{
${ }^{29}$ Kamala Subramanyam.2000. Ramayana. Surabaya : Paramita. Hal : vii

${ }^{30}$ I Gede Jaman, Ibid, Hal : 20.
} 
upacara Tahun Baru Ćaka, berupa upacara melasti, mendak toya, nyungsung, sebagaimana matur piuning yang menunjukkan kecintaan kita dengan alam lingkungan dan mahluk bawahan lainnya yang diwujudkan melalui berbagai macam upacara bhuta yajna.

Masyarakat Hindu sangat yakin bahwa ada kekuatan yang menentukan keharmonisan ekosistem yaitu : Tuhan Yang maha Esa, para deva, roh suci leluhur, dan bhutakala. Melalui berbagai upacara bhuta yadnya/tawur dan tindakan nyata dengan melestarikan alam lingkungan sekitarnya dimaksudkan untuk membina keseimbangan dan keharmonisan sesuai dengan konsep atau ajaran trihita karana. Dalam bentuknya yang terdiri dari caru sebagai perwujudan Tuhan dengan manifestasi-Nya, sehingga umat Hindu berusaha menyelaraskan antara konsep dengan kenyataan dan berharap untuk mampu membentuk hubungan yang harmonis secara keseluruhan antara manusia dengan alam. Keterkaitan dengan pola pemikiran ini adalah dengan etika yang tidak hanya melakukan interaksi dengan Tuhan dan sesama manusia, melainkan juga ada keterkaitan hubungannya dengan alam. Pemikiran Heideger memberikan sumbangan positif pada arah keseimbangan tentang interaksi manusia dan alam ${ }^{31}$. Heideger memberikan penjelasan adalah keseimbangan akan terjadi ketika manusia mampu untuk menyatukan pikiran, kebudayaan dan teknologi.

Merujuk pada pembahasan tersebut menunjukan bahwa setiap kondisi yang mampu untuk membuat eksisnya sesuatu tergantung pada dimensi jasmaniah dan rohaniah. Dimensi tersebut melekat pada hakekat manusia sebagai mahluk jasmani. Manusia yang normal selalu mendambakan kebahagiaan hidup lahir dan bhatin, keseimbangan, material dan spiritual serta keharmonisan dengan sesama dan lingkungannya. Konsep mengenai keseimbangan dan keharmonisan di dalam agama Hindu disebut dengan istilah trihita karana (Gede Jaman, 2008). Istilah Tri Hita Karana pertama kali muncul pada tanggal 11 Nopember 1966, pada waktu diselenggarakan Konferensi Daerah 1 Badan Perjuangan Umat Hindu Bali bertempat di Perguruan Dwijendra Denpasar ${ }^{32}$.

\footnotetext{
${ }^{31}$ LG. Saraswati Putri. Dimensi Ontologis Relasi Manusia dan Alam (suatu pendekatan fenomenologis lingkungan terhadap problem disekuilibrium). (Depok : UI Press, 2013), hal : 18.

32 Untung Suhardi. Kajian Bentuk Dan Makna Nilai Filosofis Lingga Dalam Perspektif Ajaran Hindu (Studi Pemujaan Lingga Di Desa Linggoasri, Kecamatan Kajen, Kabupaten Pekalongan - Jawa Tengah). Denpasar: IHDN, 2013 (tidak diterbitkan), hal : 142.
} 
Konferensi tersebut diadakan berlandaskan kesadaran umat Hindu akan dharmanya untuk berperan serta dalam pembangunan bangsa menuju masyarakat sejahtera, adil dan makmur berdasarkan Pancasila. Kemudian istilah Tri Hita Karana ini berkembang, meluas, dan memasyarakat. Secara leksikal Tri Hita Karana berarti tiga penyebab kesejahteraan.$($ Tri $=$ tiga, Hita $=$ sejahtera, Karana $=$ penyebab). Pada hakikatnya Tri Hita Karana mengandung pengertian tiga penyebab kesejahteraan itu bersumber pada keharmonisan hubungan antara: manusia dengan Tuhan, manusia dengan manusia dan manusia dengan alam.

Kata trihita karana begitu populer dikalangan umat Hindu di Indonesia. Tri hita karana itu berasal dari bahasa Sanskrta dari urat kata tri + hita + karana, yang masing-masing berarti tiga, sejahtera dan sebab. Apabila dirangkai menjadi trihita karana itu berarti tiga hal yang menyebabkan sejahtera. Secara umum tri hita karana mengandung pengertian tiga hubungan yang harmonis yaitu hubungan antara manusia dengan Tuhan (parahyangan), hubungan manusia yang harmonis dengan sesama manusia (pawongan) dan hubungan yang harmonis antara manusia dengan alam (palemahan) beserta mahluk hidup lainnya. Penerapan tri hita karana dalam konsepsi Hindu bisa kita jumpai dalam perwujudannya yaitu parhyangan, palemahan dan pawongan. Unsur- unsur Tri Hita Karana itu terdapat dalam kitab suci Bhagavad Gita (III.10), berbunyi sebagai berikut:

\section{Saha-yajñāh prajāh ș̣ștvā purovāca prajāpatih}

anena prasavișyadhvam esa wo'stv ișta kāma dhuk

Terjemahan :

Pada awal ciptaan, penguasa semua makhluk mengirim generasi-generasi manusia dan dewa beserta korban-korban suci untuk Visnu, dan memberkai mereka dengan bersabda ; berbahagialah engkau dengan yajna ini sebab pelaksanaannya akan menganugerahkan segala sesuatu yang dapat diinginkan untuk hidup secara bahagia dan mencapai pembebasan ${ }^{33}$. Berdasarkan sloka di atas bahwa dengan menerapkan Tri Hita Karana secara mantap, kreatif dan dinamis akan terwujudlah kehidupan harmonis yang meliputi pembangunan manusia seutuhnya yang astiti bakti terhadap Sang Hyang

\footnotetext{
${ }^{33}$ Prabhupada, Bhagavadgita Menurut Aslinya. (Denpasar : Hanuman Sakti, 2002). Hal : 171.
} 
Widhi Wasa/Tuhan Yang Maha Esa, cinta kepada kelestarian lingkungan serta rukun dan damai dengan sesamanya. Tri Hita Karana bermakna sebagai tiga hal yang mewujudkan kebaikan dan kesejahteraan yakni Parhyangan, yaitu hubungan yang harmonis dan seimbang antara manusia dengan Tuhan; Pawongan, yaitu hubungan yang harmonis antara manusia dengan sesama manusia; dan Palemahan, yaitu hubungan yang harmonis dan seimbang antara manusia dengan alam. Kaitan Tri Hita Karana dengan falsafah Tri Murti, Tri Kahyangan, dan Tri Kaya Parisudha, adalah: untuk mencapai tujuan hidup yang sejahtera lahir dan bathin (mokshartam jagaditaya ca iti dharmah), manusia hendaknya mampu melaksanakan Tri Kaya Parisudha: pikiran yang baik, perkataan yang baik dan benar, dan perbuatan yang baik.

Di dalam Being and Time, Heidegger memang banyak menganalisis tentang manusia sebagai mahluk penanya ada, dan bukan ada itu sendiri. Jika Heidegger tidak melanjutkan refleksi filsafatnya, maka sebenarnya ia tidak beranjak jauh dari pemikiran Husserl. Heidegger hanya melukiskan modus mengada manusia dalam kaitannya dengan dunia, tanpa menusuk langsung ke pertanyaan tentang ada itu sendiri, yang seharusnya menjadi inti dari proyek filosofisnya ${ }^{34}$.

Namun untungnya filsafat Heidegger maju lebih jauh. Ia pertama-tama memperkenalkan konsep perawatan/memelihara (care). Memelihara sendiri adalah relasi dasar antara manusia dengan alam. Karena manusia selalu berada di dalam relasi keterlibatan (involvement) dengan alam, maka sudah selayaknya ia ikut merawat dan memelihara alam itu sendiri. Tindak memelihara disini bukanlah tindakan amal, melainkan sudah melambangkan relasi fundamental antara manusia dengan alam, dan sebaliknya. Heidegger juga berpendapat bahwa manusia adalah bagian dari alam keseluruhan, karena ia selalu ada-di-dalam-dunia (being in the world). Jadi manusia dan alam berada di dalam kesatuan ontologis yang utuh serta tak terpisahkan. Maka dari itu sikap yang tepat dari manusia terhadap alam adalah sikap yang memperlakukan alam sebagai bagian dari diri manusia itu sendiri. "Kita", demikian tulis Frede dalam tulisannya tentang

34 Pada bab ini saya mengacu pada Dorothea Frede, "The Questions of Being: Heidegger's Project", dalam The Cambridge Companion to Heidegger, Cambridge, Cambridge University Press, 1993. Hal : 63 . 
Heidegger, "memproyeksikan diri kita sendiri, seluruh eksistensi kita, ke dalam dunia dan memahami diri kita dan semua hal di dunia ini dalam bentuk kemungkinan bentukan kita tentang diri kita sendiri." Manusia dan alam adalah satu, karena gambaran tentang dunia adalah gambaran manusia tentang dunia. Kedua hal itu tidak bisa dipisahkan ${ }^{35}$.

Segala sesuatu bisa diketahui, karena manusia memaknainya dan makna itu bisa diterima, karena kita, manusia, adalah bagian dari pemaknaan itu sendiri. Di dalam dunia manusia membangun dan mencipta ulang dirinya sendiri. Segala sesuatu yang bermakna bagi manusia juga sudah selalu terletak di dalam dunia. Manusia dan dunia adalah suatu proyek. Proyek adalah suatu harapan akan masa depan. Harapan akan masa depan itu tidak didasarkan pada kekosongan, melainkan pada pengertian kita tentang dunia yang ada sekarang ini. Masa lalu memang mempengaruhi manusia, namun manusia tetap terikat dan tertanam di dalam masa kini. Kekinian itulah dunia (world) yang mengikat dan memberikan makna bagi kehidupan kita sehari-hari. Manusia terhisap di dalam temporalitas kekinian, dan kekinian itulah yang mengikat manusia dengan dunia. Manusia selalu terlibat dengan dunia di dalam kekiniannya.

Bersandar dari uraian ini menunjukan tentang adanya hubungan antaramanusia dengan alam yang saling membutuhkan. Pola komunikasi yang diusung dalam Veda tidak hanya sebatas pada hubungan manusia dengan Tuhan dan sesamanya, melainkan juga ada hubungan simbiosis antara manusia dengan alam. Dengan menjadikan dasar pemikiran dan kesadaran manusia untuk menjadikan dunia ini seimbang, maka perlu sekali ditindaklanjuti secara tetap tentang program pelestarian lingkungan baik dari skala kecil dan besar. Skala kecil yang dimaksud adalah tentang kehidupan pelestarian hidup mulai dari keluarga, dan skala besar mulai dari masyarakat dan kehidupan bernegara.

\section{F. Upaya Pelestarian Etika Komunikasi Veda Dalam Kehidupan Di Era Globalisasi}

1. Mutual Understanding : Wujud Keterbukaan Setiap Individu

${ }^{35}$ Dorothea Frede, ibid, hal : 64. 
Menyandang predikat sebagai mahkluk sosial, manusia selalu terlibat dan berinteraksi dengan orang lain baik secara kelompok maupun secara personal. Dalam keterlibatannya dalam interaksi antar pribadi, manusia melakukan pertukaran pesan melalui berbagai macam simbol yang disepakati bersama dimana penggunaan pancaindra yang dimiliki dapat secara maksimal dan saling memberikan umpan balik. Komunikasi yang memang terjadi di dalam lingkup kecil (hanya antara 2-3 orang) ini memiliki pengaruh yang besar dalam perkembangan psikologis dan mutu hubungan kita dengan orang lain.

Ajaran Hindu terdapat empat tahapan kehidupan yang harus dilalui oleh setiap umat Hindu untuk mencapai tujuan hidup yang disebut catur purusartha terdiri dari dharma, artha, kama dan moksa. Dan tujuan hidup inilah yang menjadi landasan dalam pelaksanaan catur asrama ${ }^{36}$. Dalam naskah jawa kuno yaitu Agastya parwa menjelaskan tentang bagian-bagian catur asrama, dalam silakrama ini menjelaskan "Catur Asrama ngaranya brahmacari, grhastha, Wanaprasta, Bhiksuka, nahan tang catur asrama ngaranya. Artinya : yang bernama Catur Asrama ialah Brahmacari, Grhastha, wanaprasta dan Bhiksuka"37. Dari naskah ini sangat jelas dikatakan bahwa, dalam kehidupan ini hendaknya diprogramkan tahap demi tahap, sehingga dapat digariskan bahwa pada umumnya orang berada pada fase pertama kurang tepat untuk memasuki fase selanjutnya yaitu pada fase dua, ketiga apalagi langsung pada fase keempat. Karena pada masing-masing jenjang mempunyai pola hidup tersendiri dan semua jenjang ini harus dilewati sampai jenjang sanyasin, kemudian setelah semua jenjang terlewati semuanya diharapkan atman bersatu dengan sumbernya yaitu paramatman.

\section{Pengintegrasian Seluruh Komponen Hindu}

Perkembangan ilmu pengetahuan dan tekhnologi menuntut seseorang untuk selalu berpartisipasi dalam segala perubahannya. Hal yang sama juga terjadi dalam dunia komunikasi yang didalamnya dituntut untuk mengikuti tren yang ada karena jika tidak akan ditinggalkan oleh para partisipannya. Untuk itulah, perkembangan jurnalistik mengalami lonjakan yang sangat signifikan

\footnotetext{
${ }^{36}$ Kata Catur Asrama berasal dari bahasa Sansekerta yang terdiri dari catur dan asrama. Catur berarti empat dan asrama berarti tempat atau lapangan kerohania, jenjang kehidupan berdasarkan tingkatan rohani, umur dan prilaku manusia. Lihat Tim Penyusun. Svastikarana (Jakarta : PHDI Pusat, 2013),

${ }^{37}$ Naskah Sila krama, hal 8
} 
terutama untuk media masa yang didalamnya ada radio, TV dan perkembangan internet serta hal lain yang relevan dengan media penyiaran.

Peranan media masa sebagai model komunikasi masa sangat menunjang kehidupan manusia dengan pemanfaatan perkembangan komunikasi ${ }^{38}$. Seiring dengan kemajuan teknologi yang terus berkembang menuangkan hasil yang ditimbulkan dari komunikasi masa kini, hal yang menjadi fakta sekarang misalnya; bidang pers mampu mencetak surat kabar dalam jumlah banyak dengan waktu yang relatif singkat, dalam bidang film mampu untuk menyempurnakan segi audio dan visual, hal yang sama juga dialami oleh bidang radio dan televisi yang menggunakan satelit. Kemudian hal yang paling mengagumkan adalah keajaiban internet yang mampu mendekatkan semua manusia di seluruh dunia ini, sehingga dunia dalam genggaman.

Martabat manusia sebagai makhluk yang sosial (homo socius) mempunyai kewajiban untuk melakukan interaksi dengan sesamanya baik secara pribadi maupun masyarakat. Manusia sebagai individu yang mempunyai derajat tinggi jika dibandingkan dengan makhluk lainnya. Manusia dibekali dengan keunggulan yang disebut dengan pikiran (manah) yang tujuannya adalah untuk membedakan antara hal yang baik dan buruk (viveka). Kaitannya dengan kelompok komunikasi ini jika dikaitkan dengan pembinaan yang ada dalam agama Hindu berhubungan dengan komunitas yang kemudian berujung pada kelembagaan. Untuk itu, upaya pembinaan umat Hindu yang dilakukan pertama adalah tentang pengintegrasian antarlembaga Hindu. Hal awal ini sebagai senjata utama yang dihadapkan ketika melakukan pembinaan umat Hindu yang ada di DKI Jakarta. Perlunya integrasi ini adalah untuk menjalin persatuan dan kesatuan, sehingga perjuangan Hindu ini tidak memiliki kesan berjalan sendirisendiri. Oleh karena itulah, perjuangan penyatuan kelembagaan ini harus dimulai dari dalam organisasi yang kemudian berkembang keluar.

Pengamatan penulis ini bersandar dari fenomena yang nampak bahwa untuk saat ini kehadiran lembaga keagamaan Hindu membutuhkan nafas segar untuk melakukan pembenahan. Pembenahan ini mulai dari diri lembaga yang didalamnya ada administrasi kelembagaan beserta dengan strukturnya. Pembinaan

${ }^{38}$ Onong Uchjana Effendy, Ibid, hal : 83. 
yang dilakukan oleh Pembimas Hindu DKI Jakarta untuk saat ini sudah terjalin dengan baik dan bahkan keterjalinan dengan pemerintah provinsi DKI Jakarta. Selain itu, Parisada sudah mulai memunculkan dan mengaktifkan organisasi seperti WHDI, KMHDI, Peradah, Prajaniti, ICHI dan PSN serta PHDI.

Munculnya organisasi keagamaan Hindu sangat dibutuhkan karena semakin banyak muncul organisasi serupa ini akan banyak permasalahan umat Hindu yang bisa diatasi yang tidak mungkin bisa dilakukan sendiri oleh PHDI ataupun Dirjen Agama Hindu. Jadi munculnya Organisasi Keagamaan Hindu harus dilihat dari sisi yang positif. Keberadaaan ini akan menjadi penting ketika kehadiran sebuah organisasi itu mempunyai niat yang mulia, tidak asal diadaadakan atau hanya asal berbeda, apalagi jika karena egoisme atau sikap tidak mau kalah anggotanya, maka ini tidak baik bagi perkembangan Hindu ditanah air. Jika kita menoleh kebelakang Organisasi keagamaan Hindu pasca tenggelamnya RajaRaja Hindu (Majapahit Abad XV) sampai kepada jaman Republik, boleh dikatakan hampir tidak ada. Untuk itulah, dengan adanya organisasi ini dapat dengan mudah untuk dilakukannya pengkoordinasian dan pembinaan umat yang merata tanpa membedakan etnis.

Selanjutnya untuk menciptakan kerukunan intern dan antarumat beragama terkandung aspek kerukunan antarlembaga atau organisasi keagamaan. Kerukunan antarlembaga ini perlu dimantapkan sehingga pelayanan kepada umat dapat dioptimalkan. Sebab, Lembaga Keagamaan memegang peran yang sangat penting dalam pembinaan umatnya. Memahami hal tersebut dalam usaha untuk menciptakan kerukunan dan meningkatkan peran Kelembagaan Hindu dalam mengisi pembangunan serta mempererat tali simakrama antara pemerintah dan lembaga keagamaan Hindu, dalam hal ini Direktorat Jenderal Bimbingan Masyarakat Hindu Kementerian Agama R.I. sudah mengadakan Konsultasi Pejabat Ditjen Bimas Hindu Kemenag R.I. dengan pembimas Hindu dan Parisada yang ada di Indonesia. Konsultasi ini dimaksudkan untuk memperluas wawasan berorganisasi guna membangun persepsi yang sama terhadap Peran, Fungsi, Tugas, dan Tanggung Jawab dalam pembinaan umat.

\section{Modal Intelektual : Kunci Meningkatkan Kualitas SDM}

Pada dasarnya pendidikan memberikan nilai-nilai tertentu bagi individu, untuk memberikan wawasan serta menerima hal-hal baru, juga 
memberikan bagaimana caranya dapat berfikir secara ilmiah. Pendidikan juga mengajarkan kepada individu untuk dapat berfikir secara obyektif. Hal seperti ini akan dapat membantu setiap manusia untuk menilai apakah kebudayaan masyarakatnya akan dapat memenuhi kebutuhan zaman atau tidak.

Pada kenyataannya agama Hindu mendasarkan pelaksanaan agama melalui jalan bhakti dan karma, sehingga penekanannya dalam bentuk ritual dan simbolik dibandingkan dengan pemahaman dan pengetahuan serta filsafat agama. Dengan demikian agama Hindu oleh banyak pihak dipandang sebagai agama yang lebih menekankan pada bentuk ekspresif dibandingkan dengan agama dalam makna pengetahuan atau tattwa. Bentuk-bentuk ekspresif akan tampak dari rangkaian ritual dalam stages along life cycle maupun ritual-ritual agama yang ditujukan bagi kepentingan pemujaan dunia bawah maupun atas. Pada abad 21 ini menonjolkan ritual bahkan dengan besar-besaran dianggap memberatkan oleh sementara pihak. Menurut (Wiana, 2004), hal tersebut disebabkan pertama, bentuk pelaksanaan agama seperti itu dianggap terlalu membebani umat yang telah mengalami multi peran bersamaan dengan semakin terjadinya diferensiasi sosial dalam kehidupan mereka. Kedua, agama seperti itu secara sosiologis dianggap kurang sesuai dengan kondisi dan ciri kehidupan manusia abad 21 yang telah dicirikan dengan spesialisasi dan multiplikasi. Ketiga, bentuk ekspresif hanya menonjolkan bagian luar dari tatanan agama, sehingga agama yang mempolakan aktivitas seperti itu cenderung dianggap kering dari ajaran-ajaran yang bersifat konstruktif.

Perkembangan tentang dunia komunikasi yang berkembang pesat membawa dampak yang sangat pesat. Sejak jaman Yunani seperti pada tokoh Socrates dan Plato $^{39}$, yang nantinya berkembang pada media surat kabar yang banyak dibawa oleh para cendikiawan, yang menyebarkan media untuk kepentingan penyiaran. Seperti halnya, Napoleon Bonaparte ${ }^{40}$ yang lebih sesuai menggunakan media cetak karena lebih cepat untuk menyebarkan informasi 2003), hal : 3 .

${ }^{39}$ Onong Uchjana Effendy. Ilmu, Teori dan Filsafat Komunikasi, (Bandung : Citra Aditya Bakti,

${ }^{40}$ Onong Uchjana Effendy, Ibid, Hal : 7. Napoleon lahir tahun 1769 di pulau Corsica, yang saat itu berada di bawah kekuasaan Perancis. Ia tumbuh semasa Revolusi Perancis ketika paham Liberty, Equality dan Fraternity tengah didengungkan ke seantero Perancis. Ia dikirim ke sekolah militer Perancis dan pada tahun 1789 menjadi staf muda Artileri. Ia dikenal sebagai seorang pemimpin pasukan yang kompeten sejak muda dan telah dipercaya sebagai komandan artileri di Itali tahun 1794. Ketika ia kembali ke Paris pada tahun berikutnya, ia kembali dipercaya sebagai komandan angkatan perang Perancis. 
kepada seluruh jajaran kerajaan dan tentara. Hal ini menunjukan bahwa komunikasi yang ideal adalah ada kejelasan antara pemberi pesan (komunikator) dan penerima pesan (komunikan). Tentunya dalam melakukan komunikasi ini ada unsur pemahaman kepentingan, kebutuhan, kecakapan, pengalaman kemampuan berpikir antara keduanya ${ }^{41}$.

Dasar kemampuan yang dimiliki oleh diri seseorang ini sebagai modal kapital $^{42}$ yang oleh pemikiran Bourdieu bahwa memungkinkan kita untuk mendapatkan kesempatan-kesempatan di dalam hidup dengan memanfaat modal kapital. Ada banyak jenis kapital, seperti kapital intelektual (pendidikan), kapital ekonomi (uang), dan kapital budaya (latar belakang dan jaringan). Kapital dapat diperoleh, jika orang memiliki habitus yang tepat dalam hidupnya. Habitus membaca, menulis, dan berdiskusi akan menghasilkan kapital intelektual dan kapital budaya. Ditambahkan dalam pemikiran Bourdieu tentang adanya ranah sebagai ruang sosial dalam mengintegrasikan modal dan habitus. Mereka yang memiliki modal dan habitus yang sama dengan kebanyakan individu akan lebih mampu untuk melakukan tindakan mempertahankan atau mengubah stuktur dibandingkan dengan mereka yang tidak memiliki modal ${ }^{43}$.

Pernyataan yang dihadirkan oleh Bourdeau menunjukan bahwa modal awal untuk seseorang menghasilkan sesuatu adalah adanya kecakapan dalam hal intelektual. Namun demikian, dalam hubungannya dengan masyarakat bahwa seseorang tidak hanya cerdas secara personal tetapi harus cerdas secara sosial. Hubungan interaksi ini melandaskan bahwa untuk mendapatkan keduanya ini manusia dituntut untuk melakukan pengembangan diri yang mencakup adanya kecerdasan mental, emosional dan spiritual. Dalam menjalankan ketiganya ini seseorang harus mampu untuk menjadi dirinya sendiri agar dapat menjalani kehidupan ini dengan sebaik-baiknya.

Perjalanaan seseorang untuk menjadi pribadi yang unggul inilah sangat dibutuhkan segala asupan dari berbagai pihak, hal ini misalnya asupan makanan yang cukup dan seimbang, kebutuhan ekonomi, serta segala kebutuhan dalam

\footnotetext{
${ }^{41}$ Onong Uchjana Effendy, Ibid, Hal : 45.

${ }^{42}$ Piere Bourdieu. Habitus $x$ modal + Ranah $=$ praktik (Pengantar komprehensif pemikiran Piere Bourdieu, Editor : Richard Harker, Cheelen Mahar dan Chris Wilkes (Yogyakarta : Jalasutra) Sumber London: terjemahan The Macmilan Press, 1990, hal : 16.

${ }^{43}$ Piere Bourdieu, ibid, hal : xxi.
} 
hidup ini terpenuhi dengan baik. Kecakapan awal dalam komunikasi inilah yang kemudian diaktualisasikan dalam bentuk berpikir kritis dan berpikir kreatif ${ }^{44}$. Keduanya menjadi suatu hal yang penting karena untuk menjadikan seseorang yang kritis dan kreatif memerlukan upaya untuk selalu berintropeksi yang ada dalam diri dan menyesuaikan dengan lingkungannya. Kesadaran manusia untuk selalu menyadari tentang hakekat dirinya juga merupakan bagian dari sifat alamiah manusia sebagai homo religius (makhluk yang bertuhan). Oleh karenanya, manusia mempunyai interaksi secara rohani kepada yang kuasa dengan bekal pengetahuan yang dimilikinya. Hal ini juga dijelaskan dalam Bhagavadgita 4.36 yang menyatakan bahwa :

Api ced pāpebhyah

Sarwebhyaḥ pāpa-kṛt-tamah

Sarvai் jñ̄ana-plavenaiva

vẹjinamsantarișyasi

Terjemahan :

Walapun engkau dianggap sebagai orang yang paling berdosa diantara semua orang yang berdosa, namun apabila engkau berada di dalam kapal pengetahuan rohani, engkau akan dapat menyeberangi lautan kesengsaraan $^{45}$.

Penjelasan sloka Bhagavadgita ini menunjukan tentang pentingnya ilmu pengetahuan yang mulia yang dalam hal ini tidak hanya ilmu pengetahuan agama melainkan juga tentang ilmu pengetahuan yang bersifat keduniawian. Proses keseimbangan pengetahuan yang dimiliki oleh seseorang ini menjadi modal yang mampu untuk menghantarkan seseorang menuju kesadaran yang bersifat tertinggi yaitu kebahagiaan jasmani (jagadhita) dan kebahagiaan rohani (moksa). Proses pengetahuan yang dimiliki oleh seseorang ini menjadikan kesiapan yang kemudian menghantarkan seseorang menuju gerbang keharmonisan, mengingat

${ }^{44}$ Alan J. Rowe, Creative Intelegence : membangkitkan Potensi Inovasi dalam Diri dan Organisasi Anda, (bandung : kaifa PT Miza Pustaka, 2005), hal.23 dalam Soyomukti, Pengantar Ilmu Komunikasi, (Yogyakarta: Arruzz, 2012), hal 118-119.

${ }^{45}$ Swami Prabhupada, Bhagavadgita Menurut Aslinya, (Jakarta : Bhakti Vedanta Book Trust, 2000), Hal : 261. 
bahwa manusia adalah satu-satunya makhluk yang mempunyai kesadaran yang tinggi karena mempunyai tri pramana (sabda, bayu dan idep $)^{46}$. Tumbuhan hanya mempunyai bayu yang mampu hanya bergerak tetapi terbatas mengikuti arah sinar matahari dan gerakan akar yang mencari sumber mineral. Kemudian hewan yang hanya mampu untuk bersuara dan bergerak yang didasarkan atas naluri yang dimilikinya sehingga mampu untuk bertahan hidup dan melanjutkan keturunan. Namun manusia mempunyai ketiganya, yaitu dapat berpindah, bersuara dan yang paling tinggi adalah mempunyai daya pikir yang mampu untuk membedakan sesuatu yang benar dan salah.

Bekal alamiah yang ada pada diri manusia ini mampu untuk menjadikan manusia yang bermoral, berbudaya serta berakhlak mulia. Hal ini sebagai tujuan pembangunan manusia seutuhnya yang dalam hal ini membangun jiwa dan raga menuju kehidupan yang selaras, serasi dan seimbang ${ }^{47}$. Hal ini menjadi dasar bahwa keberadaan manusia sebagai objek sekaligus sebagai subjek yang dalam memperhatikan dunia ini dengan berbagai cara pandang yang berbeda dapat menuju ke arah yang positif maupun menuju ke arah yang negatif tergantung dari manusia itu sendiri. Pergulatan pemikiran ini menjadi titik tumpu manusia sebagai penentu kehidupan ini menuju kearah jauh kedepan yang tidak hanya membicarakan harta material, namun juga harus memikirkan tentang kebutuhan spiritual dalam diri orang tersebut. Sehingga kepentingan manusia ini sebagai makhluk individu dan sosial dapat tercapai dengan berpedoman pada norma agama dan norma yang ada dalam kehidupan bermasyarakat, berbangsa dan bernegara sebagai payung hukum tertinggi.

\section{Kearifan Lokal : Toleransi Hindu antar etnis}

Menurut Kamus Umum Bahasa Indonesia, Toleransi yang berasal dari kata "toleran" itu sendiri berarti bersifat atau bersikap menenggang (menghargai, membiarkan, membolehkan) yang berbeda dan atau yang bertentangan dengan pendiriannya. Toleransi juga berarti batas ukur untuk penambahan atau pengurangan yang masih diperbolehkan. Dalam bahasa Arab, toleransi biasa

${ }^{46}$ I Gusti Made Ngurah, Dasar-dasar Agama Hindu, (Surabaya : Paramita, 2003), hal : 46

${ }^{47}$ I Made Titib, Menumbuhkembangkan Pendidikan Budhi Pekerti Pada Anak, (Bandung : Ganesa Exact, 2003), hal : 14. Hal awal yang dilakukan untuk mendapatkan perilaku dari menumbuhkembangkan budi pekeri adalah dengan penanaman sifat yang baik dari kedua orangtuanya, kemudian dikembangkan dalam kehidupan bermasyarakat dan bernegara. 
disebut "tasamuh" yang artinya sikap membiarkan, lapang dada (samuhayasmuhu-samhan, wasimaahan, wasamaahatan) artinya: murah hati, suka berderma (kamus Al Munawir hal.702). Agama adalah elemen fundamental hidup dan kehidupan manusia, oleh sebab itu, kebebasan untuk beragama dan tidak beragama, serta berpindah agama harus dihargai dan dijamin. Ungkapan kebebasan beragama memberikan arti luas yang meliputi membangun rumah ibadah dan berkumpul, menyembah; membentuk institusi sosial; publikasi; dan kontak dengan individu dan institusi dalam masalah agama pada tingkat nasional atau internasional.

Kebebasan beragama, menjadikan seseorang mampu meniadakan diskriminasi berdasarkan agama; pelanggaran terhadap hak untuk beragama; paksaan yang akan mengganggu kebebasan seseorang untuk mempunyai agama atau kepercayaan. Termasuk dalam pergaulan sosial setiap hari, yang menunjukkan saling pengertian, toleransi, persahabatan dengan semua orang, perdamaian dan persaudaraan universal, menghargai kebebasan, kepercayaan dan kepercayaan dari yang lain dan kesadaran penuh bahwa agama diberikan untuk melayani para pengikut-pengikutnya. Jadi, toleransi beragama adalah menghargai dengan sabar, menghormati keyakinan atau kepercayaan seseorang atau kelompok yang lainnya ${ }^{48}$.

Persamaan membangun toleransi umat beragama serta kebebasan beragama. Toleransi dan kerukunan antar umat beragama bagaikan dua sisi mata uang yang tak bisa dipisahkan satu sama lain. Kerukunan berdampak pada toleransi; atau sebaliknya toleransi menghasilkan kerukunan; keduanya menyangkut hubungan antar sesama manusia. Jika tri kerukunan antar umat beragama, intern umat seagama, dan umat beragama dengan pemerintah terbangun serta diaplikasikan pada hidup dan kehidupan sehari-hari, maka akan muncul toleransi antar umat beragama. Atau, jika toleransi antar umat beragama dapat terjalin dengan baik dan benar, maka akan menghasilkan masyarakat yang rukun satu sama lain.

Toleransi antar umat beragama harus tercermin pada tindakan-tindakan atau perbuatan yang menunjukkan umat saling menghargai, menghormati, 
menolong, mengasihi, dan lain-lain. Termasuk di dalamnya menghormati agama dan iman orang lain; menghormati ibadah yang dijalankan oleh orang lain; tidak merusak tempat ibadah; tidak menghina ajaran agama orang lain; serta memberi kesempatan kepada pemeluk agama menjalankan ibadahnya. Di samping itu, maka agama-agama akan mampu untuk melayani dan menjalankan misi keagamaan dengan baik sehingga terciptanya suasana rukun dalam hidup dan kehidupan masyarakat serta bangsa.

Pada kenyataannya agama Hindu mendasarkan pelaksanaan agama melalui jalan bhakti dan karma, sehingga penekanannya dalam bentuk ritual dan simbolik dibandingkan dengan pemahaman dan pengetahuan serta filsafat agama. Dengan demikian agama Hindu oleh banyak pihak dipandang sebagai agama yang lebih menekankan pada bentuk ekspresif dibandingkan dengan agama dalam makna pengetahuan atau tattwa. Bentuk-bentuk ekspresif akan tampak dari rangkaian ritual dalam stages along life cycle maupun ritual-ritual agama yang ditujukan bagi kepentingan pemujaan dunia bawah maupun atas. Pada abad 21 ini menonjolkan ritual bahkan dengan besar-besaran dianggap memberatkan oleh sementara pihak. Hal tersebut disebabkan pertama, bentuk pelaksanaan agama seperti itu dianggap terlalu membebani umat yang telah mengalami multi peran bersamaan dengan semakin terjadinya diferensiasi sosial dalam kehidupan mereka. Kedua, agama seperti itu secara sosiologis dianggap kurang sesuai dengan kondisi dan ciri kehidupan manusia abad 21 yang telah dicirikan dengan spesialisasi dan multiplikasi. Ketiga, bentuk ekspresif hanya menonjolkan bagian luar dari tatanan agama, sehingga agama yang mempolakan aktivitas seperti itu cenderung dianggap kering dari ajaran-ajaran yang bersifat konstruktif ${ }^{49}$. Perubahan pola hidup masyarakat dari agraris ke industri telah pula mengubah tatanan kehidupan masyarakat modern. Masyarakat dari perspektif perubahan telah berkembang. Perkembangan ini dapat dilihat menurut tingkat-tingkat yang dikemukakan oleh Swelengrebel, yaitu: (1) tradisi kecil, (2) tradisi besar, dan (3) tradisi modern. Dilihat kasus Bali kini telah berkembang masyarakat Postmodern yaitu tradisi kecil adalah tradisi yang didominasi oleh kebudayaan pra-Hindu, seperti tampak dalam segi-segi kehidupan masyarakat dan kebudayaan yang

${ }^{49}$ Ketut Wiana. Makna Yajna dalam Agama Hindu (Surabaya : Paramita, 2004), hal : 45 
berkembang bersamaan dengan agama Hindu. Tradisi modern berkaitan dengan eksistensi unsur kebudayaan yang berkembang sejak zaman penjajahan dan kemerdekaan seperti terjadinya inkorporasi penduduk ke dalam lembaga-lembaga administrasi kenegaraan dan komunikasi bersifat global.

Perubahan struktural pun terjadi dalam kebudayaan karena banyak aktivitas kebudayaan dalam arti ritus agama secara ekspresif mengalami perubahan kedudukan dan fungsi. Tidak saja dalam makna religius, tetapi sering pula terjadi karena adanya muatan sosial, ekonomi, dan politik. Konteks ini tampak dalam aktualisasinya dari perubahan struktural terutama dapat diamati dalam kepemilikan harta yang bersifat konsumtif dan peningkatan pendidikan. Perubahan aspek kehidupan masyarakat Hindu ke arah modernisasi, di mana perubahan suatu transformasi total dari kehidupan bersama cenderung bersifat kolektif ke arah pola-pola ekonomis dan politis. Oleh karena adanya dinamika dalam masyarakat, maka pembinaan yang diberikan pun harus menyesuaikan dengan konteks kekinian.

Generasi Hindu sekarang tidak bisa menerima sesuatu dalam beragama tanpa penjelasan yang pasti. Sebagai generasi yang lahir di abad 21 ini mereka mengalami proses rasionalisasi, di mana mereka menghargai pentingnya akal sehat sebagai salah satu ciri kehidupan modem dibandingkan pertimbangan rasa dan naluri. Anak sekarang mempertanyakan, kenapa kita beragama sebatas ritual, bisakah kita beragama melalui jnana dan yoga. Hal ini tentunya menyesuaikan dengan sifat kita dan yang menjadi dasar pemahaman adalah yajna ini adalah bukan sebagai tujuan melainkan sebagai media menuju keinsyafan diri.

\section{G. Simpulan}

Berangkat dari pembahasan pada penelitian ini dengan pembahasan utama etika komunikasi yang ada dalam Veda kaitannya denga kehidupan di era globalisasi. Untuk itulah ada tiga kesimpulan yang merupakan hasil dari penelitian yang telah dilakukan, yaitu :

Bentuk komunikasi yang dahulunya hanya sebatas berbicara kepada sesama manusia, akan tetapi Hindu memberikan temuan untuk sumbangan kepada peradaban umat manusia bahwa komunikasi yang paling hakiki adalah hubungan vertikal dengan yang mahakuasa. Komunikasi yang diusung dalam pokok pemikiran Hindu inilah yang menjadikan konsep keseimbangan antara kehidupan 
rohani dan dunia yang kemudian, menjadi dasar dalam perilaku berkomunikasi dalam kehidupan pada masa kini. Dasar moralitas tentang komunikasi ini menjadikan wahana untuk seluruh umat manusia bahwa komunikasi yang baik sangatlah membutuhkan etika yang hendaknya diterapkan oleh seluruh umat manusia. Konteks berbicara ini menjadikan bahwa pola pemikiran seseorang yang tidak berpaku pada hal yang bersifat historis belaka, dan bahkan menjadikan peristiwa masa lampau sebagai dasar kebenaran. Komunikasi yang ada dalam Veda ini membawa seseorang pada tahapan untuk memahami diri dan lingkungannya karena ketika orang sudah bisa membawa diri pada hal kebaikan, maka akan ada pengaruh positif pada orang yang ada disekitar kita. Untuk itulah, komunikasi ini menjadikan diri manusia orang yang mampu untuk memahami lingkungan dan mengikuti perkembangan jaman dan perubahan yang terjadi.

Etika komunikasi yang terdapat dalam Veda ini sangatlah jelas untuk diterapkan dalam kehidupan sehari-hari. Karena pada dasarnya menunjukan tentang moralitas yang melingkupi dalam kehidupan ini baik secara verbal maupun nonverbal. Dalam kaitannya dengan proses komunukasi Veda sudah sangat lama menerapkan pola interaksi dengan sesama manusia dan lingkungannya baik secara horizontal dengan sesama manusia mulai dari keluarga, masyarakat dan bahkan untuk kepentingan bangsa dan negara. Kaitannya dengan spiritual Hindu sudah menerapkan pola komunikasi dengan sang Pencipta yaitu dengan melakukan sembah bhakti kepada Brahman sebagai asal segala yang ada.

Upaya yang dilakukan untuk melestarikan etika komunikasi dalam Veda dibentuk dengan keterbukaan individu, pengintegrasian seluruh komponen Hindu, modal intelektual sebagai titik tolak dalam kemajuan SDM, dan toleransi terhadap kearifan lokal. Upaya ini dilakukan sebagai upaya untuk menjalankan fungsi komunikasi sebagai individu dan sosial. Hal ini dimaksudkan bahwa secara individu seseorang harus menjalankan tata aturan yang berasal dari norma yang ada, sehingga dia harus terbuka dalam hal perkembangan jaman dan perubahan yang terjadi. Secara sosial etika komunikasi ini akan dipertahankan ketika sudah ada penyatuan komponen masyarakat Hindu, peningkatan SDM, dan toleransi antar etnis. Pelestarian ini dilakukan secara perlahan dengan terjalinnya semua komponen mayarakat dan mutu SDM yang dilakukan dengan cara memberikan 
sumbangan nyata bagi generasi muda yang nantinya akan melanjutkan pola kepemimpinan dan diharapkan mampu untuk melakukan perubahan secara fisik dan mental pada keadaan yang ada dan generasi selanjutnya. Dengan pendidikan tinggi inilah maka, kesadaran individu untuk menghargai sesamanya akan meningkat dan toleransi dapat diwujudkan. Semua upaya ini dilakukan sebagai wujud penerapan bahwa ketika kita berpikir harus selaras dengan perkataan dan perbuatan yang nantinya membawa dampak positif dalam kehidupan.

\section{DAFTAR PUSTAKA}

Atmaja, Nengah Bawa. 2010. Genealogi keruntuhan Majapahit Islamisasi, Toleransi dan pemertahanan Agama Hindu di Bali. Yogyakarta : Pustaka pelajar.

Berten, Kees. 1997. Etika (Seri Filsafat Atmajaya). Kanisius ; Yogyakarta.

BhaktiVedanta, A.C. (1972). Bhagavad-gita As-It-Is. Singapore: BhaktiVedanta Book Trust.

Blake, Reed H. Dan Haroldsen. Edwin O. 2003. Taksonomi KonsepKomunikasi, Penerbit Papyrus, Surabaya

Bourdieu, Piere. 1990. (Habitus $x$ modal $)+$ Ranah $=$ praktik (Pengantar komprehensif pemikiran Piere Bourdieu, Editor : Richard Harker, Cheelen Mahar dan Chris Wilkes (Yogyakarta : Jalasutra) Sumber London: terjemahan The Macmilan Press.

Bulaeng, Andi. 2004. Metode penelitian Komunukasi Kontemporer. Yogyakarta : Andi offset.

Cahyadi, Telesphorus Krispurwana. 2009. Gereja dan Pelayanan Kasih. Yogyakarta : Kanisius.

Cudamani. 1998. Bagaimana Umat Hindu Menghayati Ida Sang Hyang Widhi (Tuhan Yang Maha Esa). Surabaya : Paramita.

Cutlip, Scott M. Dan Center, Allen H. 2006. Effective Public Relation,Prenada Media Grup, Jakarta.

Danim, Sudarwan. 2002. Menjadi Peneliti Kualitatif (Ancangan Metodologi, Presentasi Dan Publikasi Hasil Penelitian Untuk Mahasiswa Dan Peneliti Pemula Bidang Ilmu Sosial, Pendidikan Dan Humaniora. Bandung : Pustaka Setia. 
Effendy, Onong Uchjana. 2003. Ilmu, Teori Dan Filsafat Kemanusiaan. Bandung : Citra Aditya Bakti.

Hanafi, Hasan. 2004. Islamologi : Dari Teosentrisme Ke Antroposentrisme. Yogyakarta : LkiS.

Hendropuspito. 2000. Sosiologi Hindu. Yogyakarta : Kanisius

Iriantara, Yosal. 2004. Manajemen Strategis Public speaking. Jakarta : Ghalia Indonesia.

Jendra, I Wayan. 1993. Berbicara Dalam Sastra Hindu Cet. 1. Jakara : Pustaka Manikgeni.

King, Larry. 2014. Seni Berbicara : Kepada Siapa Saja, Kapan Saja Dan Dimana Saja terjemah: Marcus Prihminto Widodo, editor: Tami Lesmana. Jakarta: Gramedia.

Koentjaraingrat. 2002. Pengantar Antropologi Budaya. Jakarta : Rineka Cipta.

L.Johansen, Richard. 1996. Etika Komunikasi, Penerbit Rosda, Bandung

Littlejohn, Stephen dan Karen A.Bross. 2011. Teori Komunikasi. Jakarta : Salemba Humanika.

Makmur. 2007. Filsafat Administrasi. Jakarta : Bumi Aksara.

Maswinara, I Wayan. 2006. Sistem Filsafat Hindu. Surabaya : Paramita

Mulyana, Dedi dan Jalaludin Rachmat. 2009. Komunikasi Antarbudaya : Panduan Berkomunikasi Dengan Orang-Orang Berbeda Budaya. Bandung : Rosda.

Mulyana, Dedi dan Solatun. 2007. Metode Penelitian Komunikasi (contoh penelitian kualitatif dengan pendekatan praktis). Bandung : Remaja Rosda.

Murba, I Nyoman Widana. 2007. Tuntunan praktis Dharma Wacana bagi Umat Hindu. Surabaya: Paramitha.

PHDI Pusat. 2009. Hasil-Hasil Pesamuan Agung Parisada Tahun 2009. Jakarta : PHDI Pusat. . Kompilasi Dokumen Literer 45 Tahun Parisada. Jakarta : PHDI Pusat.

Pigeaud, Th. (1938). Javaansche volksvertoningen (performances of the Javanese people). Batavia : Volkslectuur.

Praja, Juhaya. 2005. Aliran-Aliran Filsafat dan Etika. Jakarta : Kencana. 
Prayitno, Ujianto Singgih. 2014. Perubahan Sosial Dinamika Perkembangan Ilmu Pengetahuan Dan Tekhnologi Dalam Kehidupan Masyarakat. Jakarta : P3DI Sekretariat Jenderal DPR RI.

Putu Setia. 1993. Kebangkitan Hindu : Menyongsong Abad ke-21. Jakarta : Manikgeni

Richard L. Johanesen. 1996. Etika Komunikasi. Bandung : Rosadakarya Soekamto, Soerjono. 1985. Sosiologi : Suatu Pengantar. Jakarta : Rajawali

Soyomukti, Nurani. 2012. Pengantar Ilmu Komunikasi. Yogyakarta : AruzzMedia . 2013. Pengantar Sosiologi : Dasar Analisis, Teori Dan Pendekatan Menuju Analisis Masaalah-Masalah Sosial, Perubahan Sosial Dan Kajian Strategis. Yogyakarta : Arruz Media.

Suasthi dan Suastawa. 2008. Psikologi Agama (Seimbang, Pikiran, Jiwa Dan Raga. Denpasar : Widhya Dharma

Sudharta, Tjok Rai. 2003. Slokantara : Untaian Ajaran Etika Teks, Terjemahan Dan Ulasan. Surabaya : Paramita. . 2010. Mutiara-Mutiara Kebijaksanaan Veda. Jakarta : Departemen Agama Hindu.

Suryanto. (2004). Problematika Penyelenggaraan Pendidikan Berbasis Hindu Di Indonesia: Sebuah Kajian dari Perspektif Pendidikan Hindu Tradisional Model Gurukula Di India. Yogyakarta: Narayana Smrti Press.

Thantawy R. 2005. Kamus Istilah Bimbingan Dan Konseling.Yogyakarta : Grasindo.

Tim Penyusun. 2007. Pedoman Tenaga pembina (yang Disempurnakan) Ed:[I Gede Jaman]. Jakarta : Mitra Abadi press.

Tim Redaksi. 2008. Kamus Istilah Menurut Peraturan Perundang-Undangan RI 1945-2007. Jakarta : PT Tatanusa.

Titib, I Made, Made Sujana dkk.2005. Petunjuk praktis pelaksanaan Dharma Wacana. Surabaya: Paramitha.

Titib, I Made. 1996. Pengantar Weda Untuk Program DII Agama Hindu. Jakarta: Penerbit Hanuman Sakti. 
. 2003. Menumbuhkankembangkan Pendidikan Budi Pekerti Pada Anak

Dalam Perspektif Hindu. Bandung : Ganeca Exact

. 2007. Veda Sabda Suci (Pedoman Prakis Kehidupan). Surabaya :

Paramita.

Triguna, IBG Yudha, et.al.2009. Pedoman Juru Penerang Dan Penyuluh Agama Hindu. Jakarta : Dirjen Bimas Hindu.

.2009. Pedoman Pembentukan Kelompok Sasaran Penyuluh Agama Hindu. Jakarta : Dirjen Bimas Hindu

2009. Pedoman Penyiaran Agama Hindu. Jakarta : Dirjen Bimas Hindu

Wainwright. Gordon R. 2007. Membaca Bahasa Tubuh. Yogyakarta : Baca.

Wiana, I Ketut. 2006. Menyayangi Alam Wujud Bhakti Pada Tuhan. Surabaya : Paramita.

Wibowo, Hery. 2007. Forune Favors The Ready! Keberuntungan Berpihak Pada Orang-Orang Yang Siap. Bandung : Oase Mata Air Makna.

Wijana, I Dewa Putu dan Muhammad Rohmadi. 2012. Sosiolinguistik (Kajian teori dan Analisis). Yogyakarta : Pustaka Pelajar.

\section{Penelitian :}

Hemamalini, Kadek. 2013. Kajian Filsafat Ketuhanan Dalam Budaya Masyarakat Hindu Etnis Tiong Hoa Di Penjaringan Jakarta Pusat. Denpasar : IHDN (tidak diterbitkan).

Istikhori, Ahmad. 2008. Pendidikan Agama Islam Dalam Majelis Taklim Kaum Ibu RW 01 Kelurahan Tegal Parang - Jakarta Selatan. Skripsi UIN Syarifhidayattulah Jurusan Pendidikan Agama Islam, Fakultas Ilmu Tarbiyah Dan Keguruan (tidak diterbitkan).

Krisna, I Ketut. 2014. Kajian Bentuk Dan Filosofis Berbusana Umat Hindu Masyarakat Adat Bali Mewujudkan Bhakti Dan Sraddha Di Pura Aditya Jaya Rawamangun; Kajian Perspektif Budaya. Denpasar : UNHI (tidak diterbitkan).

Mandara, I Wayan Kantun. 2013. Kajian Makna Filosofis Tawur Agung Kesanga di Monas (Kajian Teologi Hindu). Denpasar : IHDN (tidak diterbitkan). 
Rahardjo, Sukirno Hadi. 2009. Metoda Pendharmawacana Sebagai Upaya Peningkatan Sradha Umat Hindu Di DKI Jakarta (Skripsi). Jakarta : STAH DN Jakarta (tidak diterbitkan).

Sari, Eka Angel Pattipi. 2011. Agama Dan Politik (Studi Tentang Refleksi Teologi Terhadap Peran Pendeta Dalam Dunia Politik. Skripsi Universitas Hasanudin, Jurusan Ilmu Politik Dan Pemerintahan (tidak diterbitkan).

Suhardi, Untung . 2013. Kajian Bentuk Dan Makna Nilai Filosofis Lingga Dalam Perspektif Ajaran Hindu (Studi Pemujaan Lingga Di Desa Linggoasri, Kecamatan Kajen, Kabupaten Pekalongan - Jawa Tengah). Denpasar: IHDN (tidak diterbitkan).

\section{Majalah/Jurnal/Prosiding Seminar}

Jro Saba dalam artikel Majalah Hindu Raditya Edisi 115 tahun 2002.

Kurniasari, NGAK. Pola Komunikasi Pemangku Hindu Di Jakarta Dalam Pemahaman Budaya Jawa Dan Bali. Media Hindu Edisi 130 Desember 2014, hal : 44-45.

Pradnya, I Made Adi Surya. Laukika dan Waidika Sebagai Konsep Komunikasi Hindu dalam Epistemologi Sabda Pramana. Jakarta : Jurnal Pasupati STAH DN Jakarta, Vol III No. 2 Juli-Desember 2014 ISSN 2303-0860, hal 77-92.

Retno Pandan Arum dkk. Identitas Sosial, Fundamentalisme, Dan Prasangka Terhadap Pemeluk Agama Yang Berbeda: Perspektif Psikologis (Jakarta : Litbang Kemenag RI, 2013) Jurnal harmoni Vol. No. 1, edisi 12 Jan-Apr 2013, hal : 21

Suhardi, Untung. 2014. Tujuan Kehidupan Manusia: Tinjauan Filsafat Kebahagiaan Menurut Epikuros Dan Catur Purusartha. Mataram : STAHN Gede Pudja, Jurnal Widya Sandi Vol. 5 No.6 Mei 2014 ISSN : 1907-7351.

Tim Penyusun. Grand Design Hindu Indonesia (Jakarta : Tim GDHI, 2014), hal : 34, Disampaikan pada workshop tanggal 22 November 2014 di Gedung Dharma Sevanam-Rawamangun, Jakarta Timur

Wirawan, I Gusti Made Arya Suta, Shadaranikarana Sebagai Model Komunikasi Hindu. Jakarta : Jurnal Pasupati STAH DN Jakarta, Vol III No.2 JuliDesember 2014 ISSN 2303-0860, hal 1-18. 


\section{Virtual (internet)}

Bagus, Denny. 2010. Komunikasi Interpersonal : Definisi, Klasifikasi, Tujuan dan Faktor yang Mempengaruhi Efektivitas Komunikasi Interpersonal. html : http://jurnal-sdm.blogspot.co.id/2010/01/komunikasi-interpersonaldefinisi.html diakses tanggal 29 September 2015.

Dwija, Bhagavan, Parisada Indonesia. Html : http://stitidharma.org/Parisada/diakses 14 Nov 2014

Fattah, Sanusi,Jono Trimanto,Juli Waskito,M.Taukit Setyawan. 2013. Perubahan Sosial Budaya dalam Masyarakat. Sumber :

Http://Nuryuwandalinda.Wordpress.Com/2013/06/18/PerubahanKebudayaan-Pada-Masyarakat/. Diunduh : 2 Des 2014 Pukul 10:34 Pm Handono, Wing. 2012. Komunikasi sosial sebagai kunci menghindari konflik. Html : http://www.suryainside.com/?mod=3\&idb=3946, diakses tanggal 27 September 2015.

Suhardi, Untung. 2014. Merpati tidak pernah ingkar janji. Html : http://hardisanatana.blogspot.com/merpati-tidak-pernah-ingkar-janji diakses tanggal 23 Oktober 2014.

Sudira, I Wayan. 2012. Pandangan Nitisastra dalam Mengelola Lingkungan. Html :http://ferrycute87.blogspot.co.id/2012/10/pandangan-nitisastradalam-mengelola.html, diakses tanggal 2 Oktober 2015.

Watimenna, Reza. 2013. Fenomenologi-Ontologi Martin Heideger, html : http://rumahfilsafat.com/2009/09/02/fenomenologi-ontologi-martinheidegger/ diakses tanggal 2 Oktober 2015. 